\title{
WSI
}

Diskussionspapiere

\section{Unemployment, Wages and \\ Collective Bargaining in the European Union}

Eckhard Hein and Thorsten Schulten

WSI-Discussion Paper No. 128

September 2004

Wirtschafts- und Sozialwissenschaftliches Institut

in der Hans-Böckler-Stiftung, Düsseldorf 
In der Reihe „WSI-Diskussionspapiere“ erscheinen in unregelmäßiger Folge Arbeiten aus dem WSI zu aktuellen Vorgängen auf wirtschafts-, sozial- und gesellschaftspolitischem Gebiet. Sie basieren u.a. auf Vorträgen, die Mitglieder des Instituts gehalten haben oder auf gutachterlichen Stellungnahmen, können aber auch Diskussionsbeiträge zu ausgesuchten Einzelthemen sein. Für den Inhalt sind die Autorinnen und Autoren selbst verantwortlich.

Dieses und andere WSI-Diskussionspapiere finden Sie als pdf-Datei unter: www.wsi.de Gedruckte Einzelexemplare sind zu beziehen über Wirtschafts- und Sozialwissenschaftliches Institut in der Hans Böckler Stiftung (WSI i.d. HBS), Hans-Böckler-Str. 39, 40476 Düsseldorf

Eckhard Hein / Thorsten Schulten WSI in der Hans Böckler Stiftung Hans Böckler Str. 39 40476 Düsseldorf

Eckhard-Hein@boeckler.de Thorsten-Schulten@boeckler.de 


\section{WSI}

Diskussionspapiere

\section{Unemployment, Wages and \\ Collective Bargaining in the European Union}

Eckhard Hein and Thorsten Schulten

WSI-Discussion Paper No. 128

September 2004 


\title{
Unemployment, Wages and \\ Collective Bargaining in the European Union
}

\author{
Eckhard Hein and Thorsten Schulten
}

\begin{abstract}
The paper questions the predominant view on unemployment and wages in the European Union according to which high unemployment is primarily caused by labour market rigidities, i.e. social institutions and regulations which prevent "market-clearing" real wage levels and structures. It is shown that the foundations of that view coming either from neo-classical or new-Keynesian theory are not convincing, neither theoretically nor empirically. Analysing the developments in the EU during the last four decades, no strictly inverse relationship between real wage growth and unemployment can be found. On the contrary, persistently high unemployment has had strong adverse effects on nominal wage growth and on the labour income share. Weakened labour union bargaining power and changing collective bargaining strategies have contributed to this result. It is therefore concluded that the current EU economic and employment policies aiming at further wage restraint, wage differentiation and decentralisation of collective bargaining are deeply misguided and have to be replaced by an alternative wage policy in Europe as part of a growth and employment oriented coordination of macroeconomic policies.
\end{abstract}

JEL classification: E24, J50

Keywords: European employment policy, wage theory, wage trends, collective bargaining 


\section{Introduction}

According to the mainstream among European economists and politicians the relation between unemployment, wages and collective bargaining seems to be rather simple. Persistent unemployment is - according to that view - the result of imperfections in the labour market caused by social institutions and regulations which prevent "market-clearing" wage levels and wage structures. Consequently, the responsibility for the persistently high unemployment in the European Union (EU) is given to so-called "structural" reasons which are mainly associated with a malfunctioning of labour market institutions such as collective bargaining, labour legislation and social security systems.

This view is currently highly influential among the EU-institutions and determines their policy recommendations in tackling the unemployment problem. The "Broad Economic Policy Guidelines", for example, which have been regularly adopted by the European Council since the mid-1990s and could be seen as the most important EU document on economic policy, have called again and again for a policy of wage restraint and increasing wage differentials (European Commission 2003a). The same requirements come from the European Central Bank (ECB) which regularly demands structural reforms in the labour market and is permanently warning off trade unions for claiming wage increases which it considers too high. Considering this, it is no surprise that the major approach to fighting unemployment within the EU is the "European Employment Strategy (EES)" which focuses almost exclusively on labour market reforms.

Regarding wage policy and collective bargaining, the recommendations made by the various EU institutions could be summarised in three points. First, they call for a policy of wage restraint, i.e. as long as there is persistent unemployment real wage increases should be below productivity growth in order to strengthen the competitiveness and profitability of the firms. Secondly, they demand a more differentiated wage structure which should reflect the different levels of productivity at regional and firm levels. Thereby, wage differentiation is often used as a euphemism for extending the low-wage sector. Finally, to adopt such a policy of wage restraint and wage differentiation a further decentralisation of collective bargaining is recommended.

The problem with this approach is that it is simply not convincing. Neither on the theoretical nor the empirical level can a strictly inverse relationship between the real wage rate and the level of unemployment be derived. Likewise there is also no strictly positive relationship between the degree of labour market regulation or the degree of wage bargaining co-ordination 
on the one hand and unemployment on the other hand. In the present paper we will therefore scrutinise the dominant view in the EU concerning labour market rigidity, wages and unemployment. We provide an alternative view which assumes that the level of employment is not determined in the labour market but by the overall level of economic activity in the goods market. Wages should therefore not only be considered as labour costs, but also play an important role for consumption demand and for the stabilisation of the price level in order to prevent both inflationary and deflationary tendencies. In our view, wages have no direct and immediate effect on unemployment. Unemployment has rather to be considered as a crucial determinant of wage developments, because the 'industrial reserve army' effect (Marx 1867: 762-801) systematically weakens the bargaining power of trade unions and threatens the established institutions of collective bargaining.

Consequently, structural reforms in the labour markets and decentralisation of wage bargaining will not be able to improve growth and employment in the EU but will weaken economic performance and contribute to the deterioration of the living conditions of a majority of people. In order to fight unemployment an alternative economic policy approach has to be pursued. This approach has to overcome the current neo-monetarist regime in which monetary policy is exclusively geared towards price stability, and fiscal policy is primarily committed to super-cyclical budget consolidation. Instead a growth and employment-oriented European coordination of macroeconomic policy is required, in which monetary and fiscal policies are responsible for growth and employment. Within such a framework wage policy would have to fulfil its macroeconomic task of stabilising both consumer demand and the overall price development. Such a macroeconomic-oriented wage policy requires a political re-strengthening of collective bargaining institutions which allows for a coordinated wage policy both at national levels and at the European level.

The present paper has the following structure. In Section 2 we discuss the theory behind the predominant view on unemployment and wages in the EU and show that it not convincing and has therefore to be replaced by an alternative view. Section 3 deals with the empirics of the developments of wages and employment in the old EU (EU 15) as a whole and in France, Germany and the UK in particular and compares them to the US. Section 4 discusses the effects of mass unemployment on collective bargaining and the changing power relations between trade unions and employers which lead to new hegemonic arrangements of wage formation. In Section 5 we will draw some final conclusions for an alternative wage policy in Europe as part of a growth and employment oriented coordination of macroeconomic policy. 


\section{On the theory of wages and unemployment}

The predominant view in the EU on wages and employment is theoretically based either on a simple neoclassical labour market view or on a more modern new-Keynesian concept of a Non-Accelerating-Inflation-Rate-of-Unemployment (NAIRU). ${ }^{1}$ In the neoclassical labour market view, whenever there is involuntary unemployment it can be wiped out by means of reducing the real wage rate in the labour market. This requires, on the one hand, that nominal wage variations have no effect on the price level and therefore translate into real wage variations. On the other hand, this view requires that Say's Law holds, i.e. effective demand by households and firms in the goods market is always sufficient to take up the goods produced and supplied by firms.

In modern new-Keynesian theory this view is rejected because changes in nominal wage costs will affect prices when firms set their prices according to a mark-up on unit costs in imperfect goods markets. Also Say's Law cannot be assumed to hold in each case when prices are far from being perfectly flexible in the face of shifts of demand. As a result, in the newKeynesian models monetary and fiscal policies can affect employment in the short run, via the impact that these policies have on effective demand in the goods market. In the long run, however, unemployment is determined by the NAIRU which is itself dependent on structural factors of the labour market, the wage bargaining and the social security system. As such, the NAIRU describes the unemployment rate at which the distribution claims by employees and employers do not result in any increase or decrease in the inflation rate. Various newKeynesian models have been put forward to determine the NAIRU: wage bargaining models in which the wage rate and employment depend on bargaining powers of trade unions and employers, efficiency wage models in which the real wage rate exerts a positive impact on productivity (shirking or fairness models) or models in which the minimum real wage rate is determined by social benefits (Blanchard and Katz 1997). When unemployment falls below the NAIRU in these models, inflation rises, and when unemployment climbs above the NAIRU the result is disinflation and deflation.

What are the forces adjusting the rate of unemployment determined by effective demand in the goods market to the NAIRU? Here modern new-Keynesian models require both symmetrical interventions by the central bank and symmetrical effects of monetary policy on the demand for goods. This means that it is the central bank which has to intervene as soon as un-

See Snowdon, Vane and Wynarcyk (1994) for a textbook treatment of different schools of thought in macroeconomic theory. 
employment falls below the NAIRU and inflation accelerates, but also as soon as unemployment climbs above the NAIRU and inflation decelerates. It is also assumed that such a symmetric central bank-reaction function will be effective, i.e. rising interest rates will always have a depressing effect on effective demand and hence on employment whereas falling interest rates always stimulate effective demand and employment.

According to the new-Keynesian view, in the long term, however, monetary policy has no influence on unemployment which is determined by structural supply side factors only. Therefore, in order to reduce unemployment, the bargaining power of trade unions and employed 'insiders' has to be reduced. To achieve this, employment protection legislation has to be dismantled, the legal conditions for wage conflict and strikes have to be confined, and human capital as well as mobility of unemployed 'outsiders' have to be improved in order to increase effective competition in the labour market. Finally, wage bargaining decentralisation is supposed to allow for a higher degree of wage dispersion and the adjustment of wages to work place productivity. These measures are said to reduce upward wage pressure and to allow for higher employment at a constant inflation rate. Assuming a given production technology with decreasing returns, rising employment is accompanied by a lower (average) real wage rate and we once again get the inverse relationship between employment and the real wage rate which is quite familiar from the simple neoclassical labour market.

This new-Keynesian view, however, also suffers from some serious deficiencies. Structural reforms in the labour market and the wage bargaining systems have an impact only on nominal wages determined in the labour market, and not on real wages, if we assume - as in the new-Keynesian approach - that in imperfect commodity markets, prices come about as a result of a mark-up being added to unit labour costs. For this reason, downward nominal wage differentiation and general wage restraint initially have an effect only on prices, and can only exert a possible influence on growth and employment if the central bank rewards this wages policy with a symmetrical and consequently more expansive monetary policy (Allsopp and Vines 1998). What is required in order for structural reforms in the labour market and concomitant nominal wage moderation to potentially lower the actual level of unemployment, is an employment and growth-oriented monetary policy which stimulates investment and effective demand. However, as a lot of papers on ECB policies have convincingly shown, this was not the case in the first years of EMU (Allsopp 2002, Bibow 2002, Hein 2002b).

But even if the central bank were to act in a more growth and employment friendly manner, the pursuit of a strategy aimed at reducing unemployment by deregulating the labour market, 
decentralising wage bargaining and enforcing nominal wage moderation on employees would entail a further risk. This kind of policy must not only rely on a symmetrical central bankreaction function as described above, but this policy also requires that monetary policy has a symmetrical effect which guarantees that unemployment determined by effective demand in the goods market adjusts to the NAIRU determined by structural factors in the labour market (Hein 2004). This, however, is very unlikely: In the short term, monetary policy may be able to choke a cumulative inflationary process caused by excessively low unemployment by means of applying the interest rate brake, thus curbing effective demand for goods and increasing unemployment. If however, during a recession, unemployment rises significantly above the NAIRU, leading to disinflation and ultimately deflation, then an interest rate cut may not be enough to stimulate an economic recovery, when firms have depressed profit expectations and are affected by debt deflation. Falling unit labour costs or even falling nominal wages will in this case exacerbate the recession and will not contribute to economic recovery. This has already been made clear by Keynes (1936: 262-271) and also follows from modern post-Keynesian theories. ${ }^{2}$ In this view the NAIRU can at best constitute a short-term employment barrier enforced by monetary policy, but it is not a long term equilibrium to which actual unemployment adjusts. ${ }^{3}$

According to Keynes and the post-Keynesians, price levels can be expected to drop, when sustained high unemployment leads to falling nominal wages or unit labour costs. But the fall in prices may not necessarily have the same extent as the fall in nominal unit labour costs, owing to specific price rigidities in the commodity market (Kalecki 1969: 56). If reductions in unit labour costs are not fully passed on to consumers in the shape of price cuts, the result is a redistribution at the expense of wage earners and a concomitant fall in this group's consumption demand. However, if domestic prices fall in an open economy, the balance of trade improves, as long as this is not counteracted by the exchange rate or unit labour cost trends abroad, although this is likely if there are long-term disequilibria in the balance of trade. If households and businesses expect nominal wages and prices to continue to fall, consumption expenditures and investments are postponed and current effective demand declines. Even if the central bank cuts interest rates in the face of a deflationary recession, the potential expan-

\footnotetext{
$2 \quad$ See also Kalecki (1969: 55-59). For the post-Keynesian view on wages and prices see Kalecki (1954: 11-27) and Lavoie (2001).

3 In contrast to the new-Keynesian view, the post-Keynesian approach sees no reason to assume that the unemployment rate determined by effective demand in the commodity market will adjust to the NAIRU, which is determined by structural and supply-side factors (Sawyer 2001, 2002). On the contrary, it can be shown that in the long term the NAIRU adjusts endogenously to the actual unemployment rate (Hein 2004).
} 
sive effect on investment and consumption is counteracted by the fact that in a modern credit money economy falling prices imply a redistribution of wealth from debtors to creditors with the associated risk of over-indebtedness. This debt deflation effect (Fisher 1933) serves to dampen investment and consumption if the realistic assumption is made that creditors are less inclined to spend than are debtors. Furthermore, it is more difficult to obtain credit to finance spending in a debt deflation scenario, since banks' and financial intermediaries' lending policy is determined by the creditworthiness of households and firms applying for loans, and their real indebtedness is an important indicator of how creditworthy they are.

If one realistically assumes the characteristics of a modern credit money economy as described in this post-Keynesian approach, it can thus be said that in times of recession, wage trends are the anchor to prevent deflationary processes, even if the monetary policy response also favours growth and employment. Organised labour markets, effective wage bargaining co-ordination and rigid nominal wages should therefore not be considered as obstacles to more employment and growth but rather as macroeconomic stabilisers and preconditions for a better macroeconomic performance. From this it also follows that instead of using the monetary policy instrument in case of inadequate wage developments, macroeconomic wage externalities can be internalised more effectively by taking a macroeconomic approach to coordinating wages policy. ${ }^{4}$ In this approach nominal wage growth rates should be determined by the sum of long-term productivity growth for the economy as a whole and the central bank's inflation target. Nominal unit labour costs growth should therefore be equal to the target rate of inflation of the central bank. This firstly means that 'effective co-ordination' of wage bargaining is able to reduce inflationary pressures when employment is rising and in so doing to lower the employment limit expressed in the NAIRU. ${ }^{5}$ Such a course makes it possible for the central bank to tolerate a higher level of employment while still meeting its inflation target. Secondly, during a phase of rising unemployment, co-ordinated wage bargaining can lessen the pressure for wage reductions and thereby reduce the risk of macroeconomically destabilising deflationary processes.

This has been shown recently in a series of studies on the interaction between wage bargaining systems and independent central banks. Franzese (2001), Soskice and Iversen (2001) and Hein (2002a) each present overviews containing implications for the EMU.

5 What is meant here by 'effective co-ordination' of wages policy is a functioning horizontal coordination between the sectors of industry which is accompanied by a functioning vertical co-ordination within the sectors (Traxler et. al. 2001), which solves the problem of implementation and prevents earnings drift and wage dumping. 


\section{Wages, prices and unemployment - a look at the data}

In order to assess the relevance of the neoclassical or new-Keynesian view on wages and employment underlying the deregulationist labour market policies in the EU compared to the alternative post-Keynesian view, in the following paragraphs we will analyse the development of the unemployment rate, the inflation rate, the growth rates of nominal and real wages and the labour income share from 1960 until 2004 (Table 1, see also the Figures in the appendix). Our analysis focuses on the development in the old EU countries as a whole (EU 15), but we will also take a look at the developments in the largest EU countries -Germany, France and the UK- and compare them with the USA. Since the variables in question display marked cyclical fluctuations we will only make some statements about middle to long term trends when analysing the relationships between these variables.

\section{Real wages and employment}

For the neoclassical and new-Keynesian view to claim empirical relevance, we should observe a close long term relationship between real wage growth and the unemployment rate, i.e. falling (rising) real wage growth should be associated with falling (rising) unemployment. For the EU 15 this is definitely not the case: Periods of steeply rising unemployment rates in the mid 1970s, the first half of the 1980s and the early 1990s were associated with falling growth rates of real compensation per employee (Table 1 and Figure 1). And the reduction in unemployment since the mid 1990s has been accompanied by a slight increase in real wage growth. For the US we find a similar picture contradicting the neoclassical and newKeynesian claims: increasing unemployment from the late 1960s to the early 1980s was associated with a decrease in real wage growth, whereas the decrease in the unemployment rate since the mid 1990s has been accompanied by a slight tendency of increasing real wage growth (Table 1). Only the US development from the mid 1980s to the early 1990s is in accordance with the neoclassical and the new-Keynesian view: we see a parallel development of unemployment and real wage growth. Taking a look at the developments in Germany, France and the UK our general conclusion is confirmed: there is no stable long rung term positive relationship between real wage growth and unemployment. On the contrary, in general we find an inverse relationship between the two variables, i.e. rising unemployment is associated with falling real wage growth, and there are only a few short periods in which the neoclassical and new-Keynesian assertion seems to hold, for example in the UK in the early 1990s or in France since the late 1990s. 
Table 1: Unemployment rate, inflation rate, nominal wage growth, real wage growth, labour income share in the EU, Germany, France, the UK and the USA, 1960 - 2004, 5-years annual average values, in \%

\begin{tabular}{|c|c|c|c|c|c|c|c|c|c|c|}
\hline & & 1960-1964 & 1965-1969 & 1970-1974 & | 1975-1979 & | 1980-1984 & 1985-1989 & | 1990-1994 & | 1996-1999 & |2000-2004 \\
\hline$\overline{\text { EU15 }}$ & $\begin{array}{l}\text { Unemployment rate } \\
\text { Inflation rate }^{1} \\
\text { Nominal compensation per employee }^{2} \\
\text { Real compensation per employee }^{3} \\
\text { Labour income share }^{4}\end{array}$ & $\begin{array}{c}1.9 \\
3.6 \\
9.1 \\
5.3 \\
72.3\end{array}$ & $\begin{array}{c}2.2 \\
3.7 \\
8.1 \\
4.3 \\
72.2\end{array}$ & $\begin{array}{c}2.4 \\
8.0 \\
13.5 \\
4.8 \\
72.8\end{array}$ & $\begin{array}{c}4.5 \\
10.4 \\
12.1 \\
2.6 \\
74.6\end{array}$ & $\begin{array}{c}7.7 \\
9.8 \\
9.1 \\
0.3 \\
74.1\end{array}$ & $\begin{array}{c}8.9 \\
4.2 \\
5.1 \\
1.4 \\
70.9\end{array}$ & $\begin{array}{c}8.9 \\
4.5 \\
4.3 \\
1.2 \\
70.6\end{array}$ & $\begin{array}{c}9.7 \\
2.1 \\
3.1 \\
0.5 \\
68.3\end{array}$ & $\begin{array}{c}7.8 \\
2.0 \\
3.0 \\
1.2 \\
68.5\end{array}$ \\
\hline Germany $^{5}$ & $\begin{array}{l}\text { Unemployment rate } \\
\text { Inflation rate }^{1} \\
\text { Nominal compensation per employee }^{2} \\
\text { Real compensation per employee }^{3} \\
\text { Labour income share }^{4}\end{array}$ & $\begin{array}{c}0.5 \\
2.9 \\
8.4 \\
5.4 \\
70.2\end{array}$ & $\begin{array}{c}0.8 \\
2.4 \\
7.3 \\
4.8 \\
69.5\end{array}$ & $\begin{array}{c}0.9 \\
5.6 \\
12.0 \\
6.0 \\
71.8\end{array}$ & $\begin{array}{c}3.1 \\
4.0 \\
6.4 \\
2.3 \\
72.1\end{array}$ & $\begin{array}{r}5.2 \\
4.5 \\
4.2 \\
-0.3 \\
71.8\end{array}$ & $\begin{array}{c}6.4 \\
1.2 \\
2.8 \\
1.6 \\
68.4\end{array}$ & $\begin{array}{c}6.5 \\
3.5 \\
5.6 \\
2.1 \\
68.7\end{array}$ & $\begin{array}{c}8.8 \\
1.4 \\
1.6 \\
0.2 \\
67.3\end{array}$ & $\begin{array}{c}8.5 \\
1.3 \\
1.7 \\
0.4 \\
67.0\end{array}$ \\
\hline France & $\begin{array}{l}\text { Unemployment rate } \\
\text { Inflation rate }^{1} \\
\text { Nominal compensation per employee }^{2} \\
\text { Real compensation per employee }^{3} \\
\text { Labour income share }^{4}\end{array}$ & $\begin{array}{c}1.5 \\
4.1 \\
10.7 \\
6.4 \\
75.3\end{array}$ & $\begin{array}{c}2.0 \\
4.1 \\
8.5 \\
4.2 \\
74.0\end{array}$ & $\begin{array}{c}2.7 \\
7.8 \\
12.4 \\
4.2 \\
73.3\end{array}$ & $\begin{array}{c}4.8 \\
10.2 \\
14.1 \\
3.6 \\
77.3\end{array}$ & $\begin{array}{c}7.7 \\
11.0 \\
12.2 \\
1.1 \\
78.9\end{array}$ & $\begin{array}{c}9.7 \\
3.6 \\
4.6 \\
0.9 \\
73.8\end{array}$ & $\begin{array}{c}10.2 \\
2.7 \\
3.4 \\
0.6 \\
70.1\end{array}$ & $\begin{array}{c}11.4 \\
1.3 \\
2.4 \\
1.1 \\
69.0\end{array}$ & $\begin{array}{c}9.1 \\
1.7 \\
2.5 \\
0.8 \\
68.9\end{array}$ \\
\hline UK & $\begin{array}{l}\text { Unemployment rate } \\
\text { Inflation rate }^{1} \\
\text { Nominal compensation per employee }^{2} \\
\text { Real compensation per employee }^{3} \\
\text { Labour income share }^{4}\end{array}$ & $\begin{array}{c}1.5 \\
2.8 \\
5.7 \\
2.8 \\
72.0\end{array}$ & $\begin{array}{c}1.7 \\
4.3 \\
6.8 \\
2.5 \\
72.2\end{array}$ & $\begin{array}{c}2.4 \\
9.3 \\
13.8 \\
4.2 \\
72.9\end{array}$ & $\begin{array}{c}4.5 \\
15.2 \\
16.8 \\
1.4 \\
73.3\end{array}$ & $\begin{array}{c}9.2 \\
9.1 \\
11.1 \\
1.8 \\
73.1\end{array}$ & $\begin{array}{c}9.7 \\
5.0 \\
7.9 \\
2.8 \\
72.4\end{array}$ & $\begin{array}{c}8.9 \\
5.1 \\
6.3 \\
1.1 \\
73.9\end{array}$ & $\begin{array}{c}7.1 \\
2.7 \\
4.2 \\
1.5 \\
70.7\end{array}$ & $\begin{array}{c}5.1 \\
1.6 \\
4.7 \\
3.1 \\
72.9\end{array}$ \\
\hline$\overline{\mathrm{USA}}$ & $\begin{array}{l}\text { Unemployment rate } \\
\text { Inflation rate } \\
\text { Nominal compensation per employee }^{2} \\
\text { Real compensation per employee }^{3} \\
\text { Labour income share }^{4}\end{array}$ & $\begin{array}{c}5.8 \\
1.2 \\
4.2 \\
2.9 \\
70.8\end{array}$ & $\begin{array}{c}3.9 \\
3.0 \\
5.5 \\
2.5 \\
69.6\end{array}$ & $\begin{array}{c}5.4 \\
5.6 \\
7.5 \\
1.7 \\
71.4\end{array}$ & $\begin{array}{c}7.1 \\
7.2 \\
8.3 \\
1.0 \\
69.6\end{array}$ & $\begin{array}{c}8.3 \\
6.6 \\
7.5 \\
0.9 \\
69.8\end{array}$ & $\begin{array}{c}6.2 \\
3.5 \\
4.2 \\
0.6 \\
68.6\end{array}$ & $\begin{array}{c}6.5 \\
3.1 \\
4.0 \\
0.9 \\
68.3\end{array}$ & $\begin{array}{c}4.9 \\
1.7 \\
3.5 \\
1.7 \\
67.1\end{array}$ & $\begin{array}{c}5.2 \\
1.8 \\
3.1 \\
1.3 \\
66.9\end{array}$ \\
\hline
\end{tabular}

\footnotetext{
${ }^{1}$ deflator of private consumption, annual growth rate in $\%$

2 annual growth rate in $\%$

3 annual growth rate in $\%$

${ }_{5}^{4}$ as percentage of GDP at current factor cost, total economy

${ }^{5}$ until 1990 West Germany
}

Source: European Commission (2004), AMECO database, own calculations 
Figure 1: Unemployment rate and real wage growth in EU15, 1960 - 2004, in \% Source: European Commission (2004), AMECO database

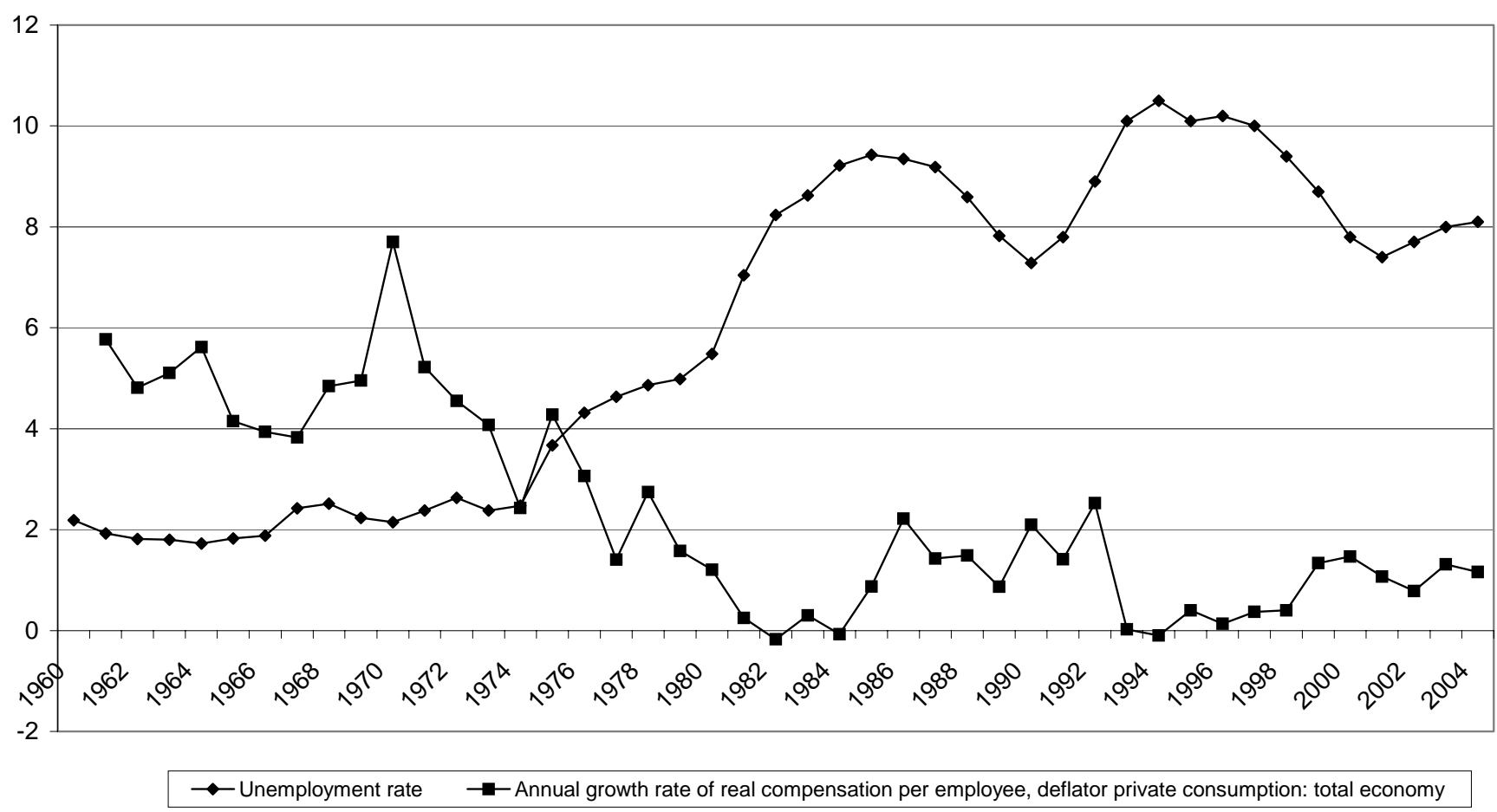

\section{Nominal wages and prices}

Instead of a close relation between real wage growth and unemployment, the post-Keynesian view advocated in the present paper claims a close relation between nominal wages and the price level. We should therefore observe a close long term relationship between nominal wage growth and inflation. Assuming mark-up pricing on unit labour costs, the relation between nominal wage growth and inflation is of course affected by productivity growth and changes in the mark-up. Therefore, we should have compared unit labour costs growth with inflation where the relation is very close (see Hein, Schulten and Truger 2004). Since productivity growth cannot be controlled by wage bargaining, however, we prefer to analyse the relation between nominal wage growth and inflation in the present paper. For the EU 15 countries this relation seems to be quite close, too (Figures 2). The same is true when we look at the data for Germany, France and the UK as well as for the US (Table 1): A rising (falling) growth rate of nominal compensation per employee is usually associated with rising (falling) inflation rates. Therefore, Keynes's and the post-Keynesian view with respect to the relation between nominal wages and inflation are supported by the data. Decreasing nominal wage growth has been responsible for the considerable decline in inflation since the early 1980s. Excessive wage 
moderation has recently even caused serious deflation risks in Germany, the largest EU economy, as the IMF (2003) has also acknowledged (see Hein/Schulten/Truger 2004).

Figure 2: Inflation rate and nominal wage growth in EU15, 1960 - 2004, in \% Source: European Commission (2004), AMECO database

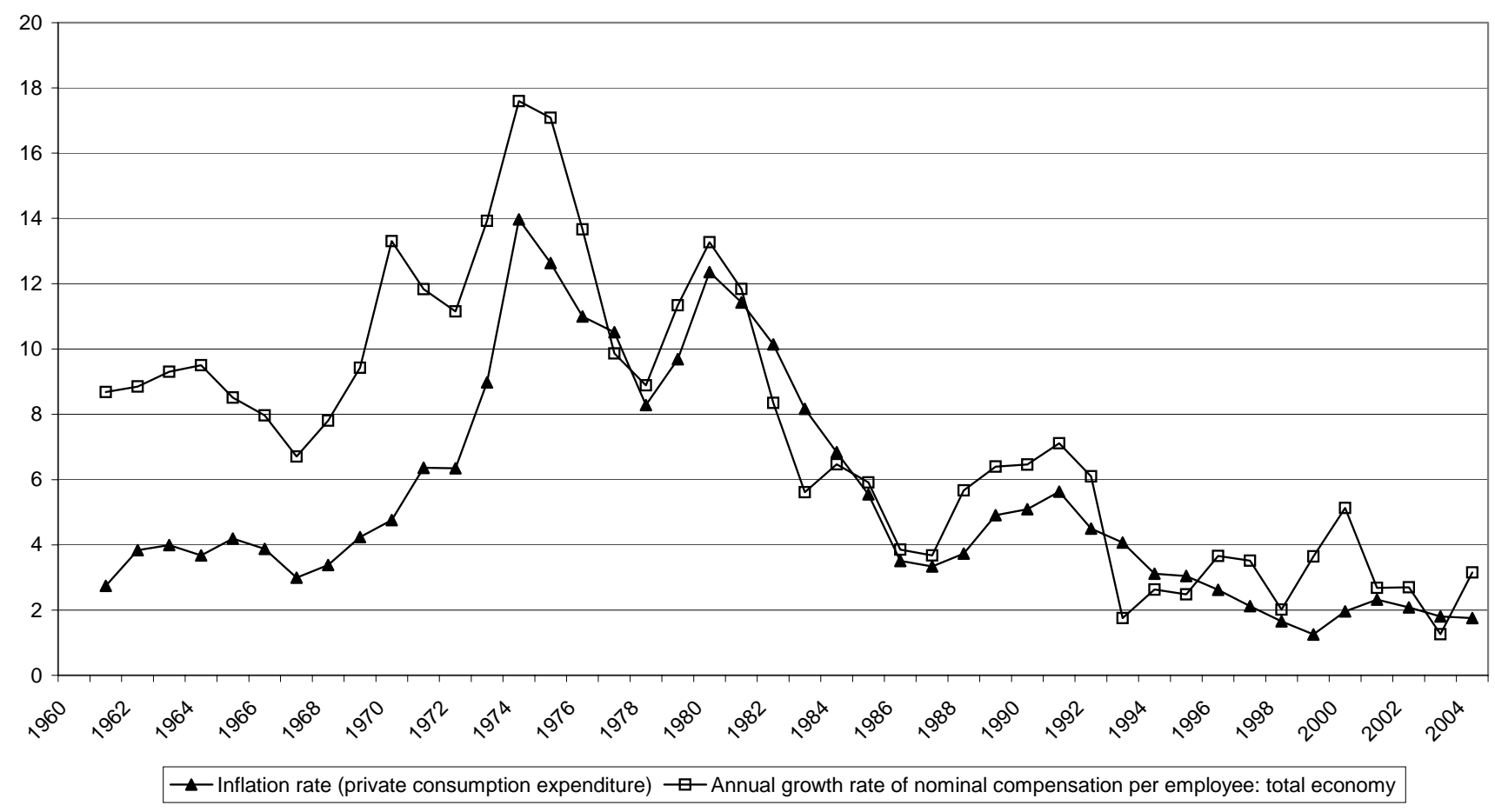

Unemployment, nominal wages and labour income shares

Finally, we have to address the relation between unemployment, nominal wage growth and distribution. The new-Keynesian NAIRU-models as well as the post-Keynesian theories of wages and prices imply that rising (falling) unemployment should be associated with falling (rising) nominal wage growth, because unemployment is an important determinant of the trade unions' power to push through higher nominal wages. Indeed, for the EU 15 as a whole and for Germany, France and the UK in particular, we find that the fall in nominal wage growth from its peak in the mid 1970s until the mid 1980s had been associated with a continuous increase in the rate of unemployment (Table 1 and Figure 3). In the US nominal wage growth only stopped increasing when unemployment peaked in the early 1980s. Slowing down the economy by means of restrictive monetary as well as fiscal policies, and increasing unemployment can be considered as the means to reduce nominal wage pressure and hence to bring down inflation. This instrument was introduced once again when unemployment decreased in the late 1980s/early 1990s and nominal wage growth started to accelerate. The re- 
cession in the early 1990s increased unemployment and limited the capacity of trade unions to push through higher nominal wage hikes. Slow nominal wage growth has been imposed since then by persistently high unemployment in the EU 15 as a whole and in Germany and France in particular. In the UK and in the US, however, falling unemployment improved the conditions for faster nominal wage growth in the second half of the 1990s. The recession in 2001 with rising unemployment put a stop to accelerating nominal wage growth in the US.

Figure 3: Unemployment rate and nominal wage growth in EU15, 1960 - 2004, in \% Source: European Commission (2004), AMECO database

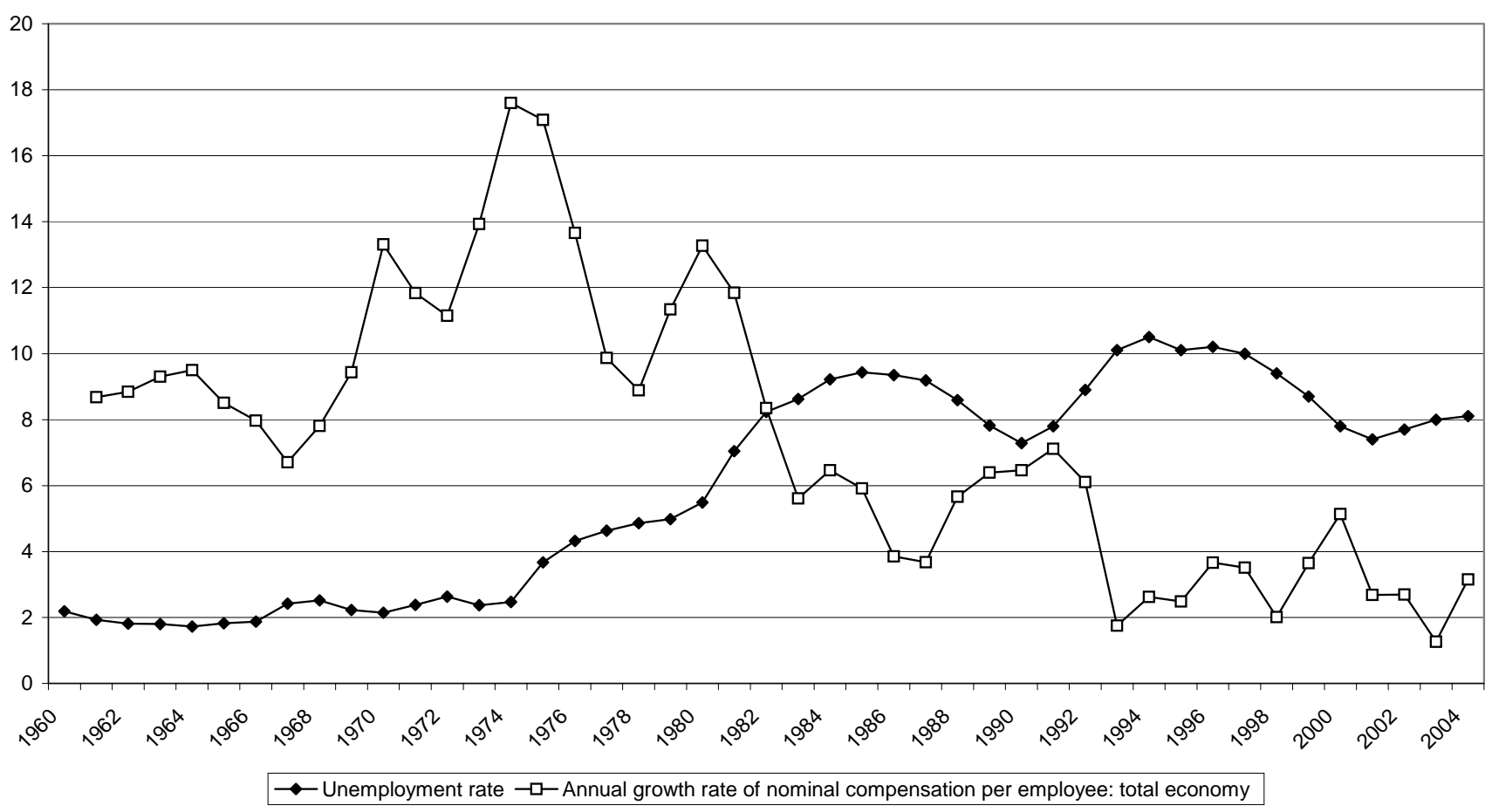

Nominal wage moderation and the associated dampening of nominal unit labour cost growth imposed by high unemployment is not completely passed on to prices by firms in each period in each country. Accordingly, unemployment may have major effects on functional income distribution (Figure 4, Table 1). In the EU 15 as a whole and in Germany and in France in particular, a rising tendency of unemployment rates since the mid 1970s has been accompanied by a tendency of the labour income share to fall since the early 1980s until the present. In the US, however, there seems to have been a tendency of the labour income share to fall since the early 1970s which is quite independent of the development of unemployment (Table 1) whereas the UK displayed a remarkable constancy in functional income distribution instead of a considerable increase in unemployment from the mid 1970s until the mid 1980s and a decrease since the mid 1990s. 
Figure 4: Unemployment rate and labour income share in EU15, 1960 - 2004, in \% Source: European Commission (2004), AMECO database

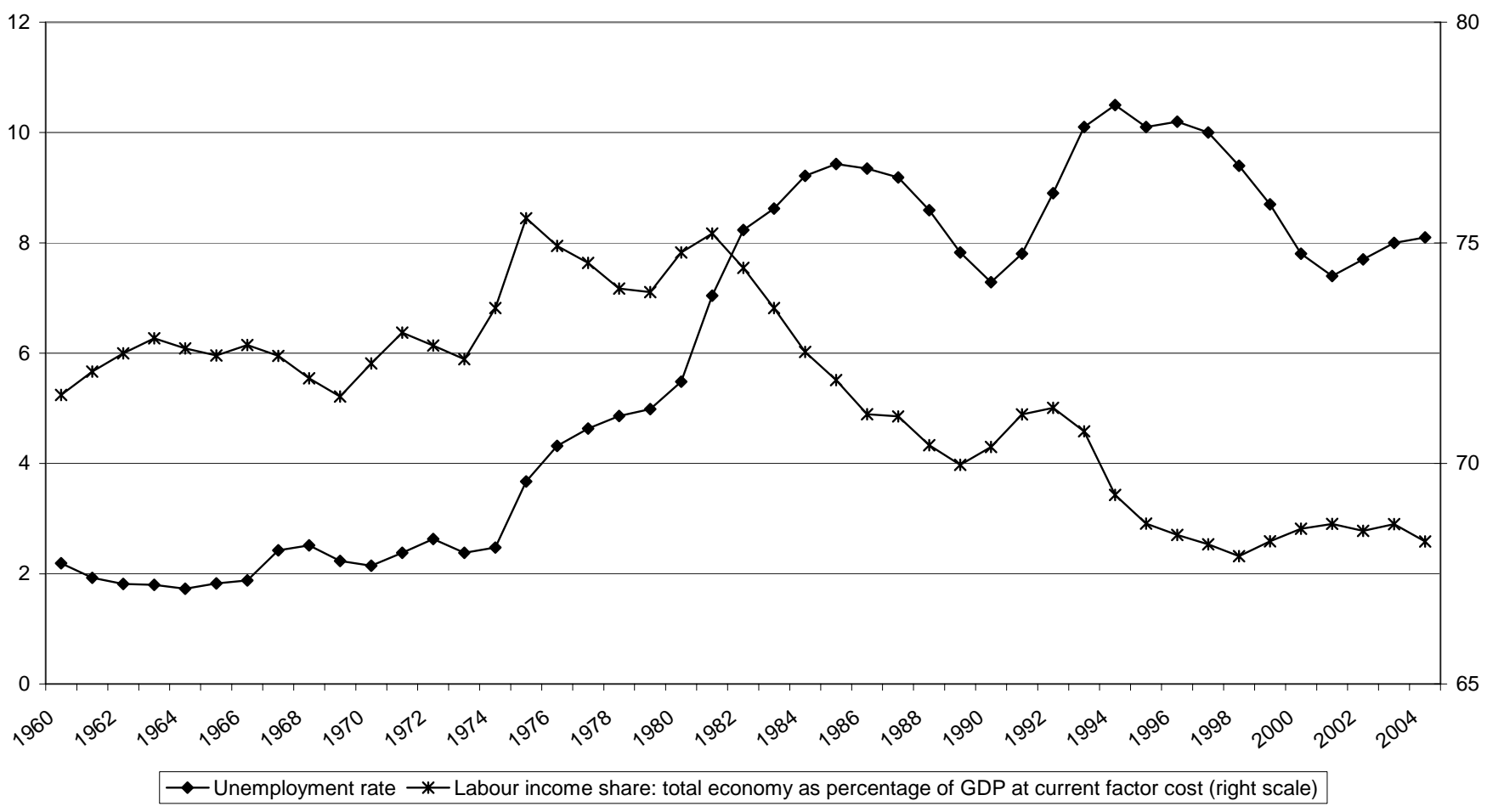

We can now sum up our empirical findings as follows: 1). There is obviously no clear positive relation between real wage growth and unemployment as expected by neoclassical or newKeynesian models. On the contrary, the data for the different countries advocate a tendency towards an adverse relation, i.e. a slowdown of real wage growth in periods of rising unemployment and acceleration in periods of falling unemployment. A crucial reason for this is that periods of high growth and falling unemployment are usually accompanied by rising productivity growth (Verdoorn's law) allowing for higher real wage growth without compressing profits or generating inflation. Thus, improving employment and rising real wage rates can be considered as the joint result of a healthy performance in the goods market 2). There is a clear indication of a close and positive relation between nominal wage growth and inflation. Keynes's and the post-Keynesian view on the primary effect of wage variations on prices are confirmed. 3). Unemployment has a clear cut inverse effect on nominal wage growth. Increasing unemployment by means of slowing down effective demand in the goods market has been the tool to bring down nominal wage pressure and hence inflation. 4). The dampening effect of unemployment on nominal wage growth has not only brought down inflation, but has also had a negative effect on labour income shares in the EU as a whole and in Germany and France in particular. Here, this contributed to the relatively weak macroeconomic perform- 
ance in the 1990s compared to the UK and the US and to the persistence of high unemployment in continental Europe. ${ }^{6}$

\section{The impact of unemployment on wages and collective bargaining}

The theoretical and empirical arguments we provided in the previous section clearly disprove the basic assumption of the European economic mainstream that real wage developments determine the level of unemployment. On the contrary there seems to be more an inverse relation because periods of relatively low unemployment (1960s and 1970s) showed relatively high increases of real wages while in periods of high unemployment (1980s and 1990s) real wage increases were comparatively low. The distinct correlation between high unemployment and falling nominal wage growth as well as a decreasing share of labour income since the 1980s makes it clear that unemployment has had an important social function in decreasing inflation and regulating the distributional conflict between labour and capital.

It was Karl Marx (1867: 762-801) who was one of the first to analyse very precisely the social function of what he called the "industrial reserve army" of unemployed which to him was the unavoidable result of capital accumulation regularly undermining the bargaining power of trade unions. Later, it was Michal Kalecki (1943) in particular who put the focus on the "political aspects of full employment". Since the employment question is always embedded in the distributional conflict between different social groups and classes it would be naive to assume that all these groups would have the same strong interest in diminishing unemployment. For "business leaders" a certain rate of unemployment has always been an important tool to safeguard "discipline in the factories" and to avoid the workers and their trade unions from becoming too strong. Therefore, "their class instinct tells them that lasting full employment is unsound from their point of view, and that unemployment is an integral part of the 'normal' capitalist system" (ibid.: 351). The NAIRU concept seems to give these class interests a modern expression and might also be read as the "non accruing indiscipline rate of unemployment" (Petit 1998).

High unemployment weakens the bargaining power of trade unions in at least three ways: First, in most European countries the sharp raise of unemployment in the 1980s and 1990s went along with a large decline in trade union membership (Ebbinghaus and Visser 2000,

$6 \quad$ See Hein and Truger (2004a, 2004c) for a more extensive analysis of the weak economic performance of the EMU countries caused by macroeconomic mismanagement. 
Boeri et. al. 2001). The losses of jobs were particularly high in those sectors (e.g. manufacturing or public sector) which traditionally showed a high rate of trade union density. Most trade unions have had great difficulties in recruiting new members in the expanding sectors (e.g. private services) and the overall trade union density has shown a steady decline. There are only four European countries (Belgium, Denmark, Finland and Sweden) in which the rate of unionisation has been rather stable or has even been increasing. All these countries, however, belong to the so-called "Ghent-system", where the unemployment insurance is administrated by union-affiliated institutions. Under such a system increasing unemployment is a further incentive for employees to join the trade unions (Boeri et.al. 2001: 22).

Secondly, against the background of persistently high unemployment in the 1980s and 1990s most European countries have followed the policy recommendations by the economic mainstream and have started to deregulate labour market institutions (for an overview see Lodovici 2000). The core of these deregulation strategies has been a relaxation of employment protection, a legal widening of the possibilities to use various forms of non-permanent employment (notably fixed-term contracts, temporary agency work and casual or seasonal work) and a reduction of the amount and duration of unemployment benefits in order to reduce the socalled "reservation wage". As a result in many European countries the proportion of employees working in precarious jobs with fixed-term contracts and often low payment has shown a significant increase (European Commission 2003b). This has also contributed to a further weakening of trade unions, because it is much more difficult for them to organise employees working in precarious jobs (Boeri et. al. 2001: 24ff.). At the same time, the growing importance of precarious employment puts significant downward pressure on the working conditions of "regular" employees.

Thirdly, high unemployment has had a strong impact on the institutions of collective bargaining and the dominant forms of wage formation (on the following see: Traxler et. al. 2001: 105-143). In the 1950s and 1960s most European countries established multi-employer bargaining systems with negotiations at sectoral or even at national levels and a national coordination of wage policy. Under the conditions of full employment employers were particularly interested in multi-employer bargaining because it helped to secure wage moderation by containing inter-firm competition for scarce labour. Moreover, the employers supported corporatist incomes policy as an opportunity to prevent trade unions from taking advantage of their strong bargaining power at company level. 
For the unions the multi-employer bargaining and corporatist incomes policy had ambiguous effects. On the one hand, it allowed them to follow a "solidaristic wage policy" aiming to fulfil the principle of "equal pay for equal work" and to reduce wage inequalities between different groups of employees. ${ }^{7}$ Furthermore, corporatist arrangements strengthened trade union influence on the overall policy development in areas such as economic, social and labour market policy. On the other hand, trade unions had to accept a policy of wage moderation with real wage increases in line with average productivity growth. In practice, however, good performing companies often paid above the collectively agreed rate to attract certain groups of employees and, therewith, caused a substantial wage drift. Considering this, in the late 1960s and early 1970s it were the trade unions which first of all called for a strengthening of company bargaining in order to regain the influence on actual wage developments.

The fundamental changes in the power relations between employers and trade unions caused by the sharp increase in unemployment in the 1980s went along with a principle shift of interest regarding the institutions of collective bargaining. From then on it was the employers who demanded a more or less radical decentralisation of collective bargaining, while the trade unions tried to defend multi-employer bargaining and coordinated wage policies as an institutional barrier against further loss of bargaining power.

At first sight, one could get the impression that trade unions have been rather successful because during the last two decades none of the EU 15 countries - with the exception of the UK - have shown a radical shift from multi-employer to company bargaining (Schulten 2004a: 170-178, Traxler et. al. 112-143). Without such radical changes, however, there has been a more or less far reaching decentralisation within the framework of traditional multi-employer bargaining systems. This has included forms of "controlled" or "organised" decentralisation whereby employers and trade unions established multi-level bargaining systems and/or agreed upon the introduction of opening-clauses into sectoral agreements which determine some criteria for diverging company agreements. It has also included forms of "wild" or "nonorganised" decentralisation whereby companies simply contravene valid collective agreements.

In addition to that, in the 1990s many European countries were faced by the creation of new bargaining arrangements which explicitly aimed at a policy of wage restraint in order to increase competitiveness which became widely regarded as the decisive prerequisite for the

$7 \quad$ On the principle of solidaristic wage policy and theoretical foundations of trade union wage policies in Europe see Schulten (2004a, 2004b). 
safeguarding and creation of employment (Bieling and Schulten 2003, Schulten 2004a: 245275). These new bargaining arrangements could be found both at company and at national level. At company level so-called "pacts for employment and competitiveness" have emerged following the principle of "concession bargaining" whereby employees had to agree to labour cost reductions (e. g. extension of working time or reduction of pay) in exchange for limited job guarantees given by the company (Sisson 2001). At national level many European countries saw a renaissance of tripartite social pacts which established a new form of "competitive corporatism" the primary aim of which was to secure a policy of wage restraint with real wage increases below productivity growth in order to strengthen national competitiveness (Fajertag and Pochet 2000).

To sum up, the persistently high level of unemployment in Europe has already led to a notable deregulation of labour market institutions. All these changes have contributed to a significant weakening of trade unions and to a transformation of collective bargaining which have become more and more dominated by the principle of "concession bargaining", whereby wage restraint and cuts in labour costs are regarded as the "magic formula" to create employment. In practice, however, none of these institutional changes have led to a substantial reduction of European unemployment so far. As various recent studies have shown, there is no statistically evident correlation between labour market institutions and employment performance (Aidt and Tzannatos 2002, Baker et.al. 2002, Hein and Truger 2004c, OECD 2004). Neither the level of union density nor the standard of statutory employment protection or the nature of the collective bargaining systems - nor the regulations of the welfare state - have clear cut effects on unemployment.

The only statistically significant correlation could be found between labour market institutions and the overall wage dispersion. A higher union density, stronger employment protection and centralised or coordinated collective bargaining tend to compress the wage structure. Consequently, in the 1990s the deregulation of labour market institutions contributed to an increase of wage differentials and an extension of low wage sectors in many European countries (Schulten 2004a: 200ff.). In contrast to what is maintained by the economic mainstream there is, however, no clear trade-off between employment performance and wage differentiation (Howell and Huebler 2004). While low wage differentials have an important positive impact on income equality and social cohesion they can go along with both a low or high level of employment. All in all, there is a strong "indication that quite different institutional arrangements are capable of obtaining similar levels of macroeconomic performance" (OECD 2004: 130). 


\section{Conclusion}

At the Lisbon European Council in March 2000, the European Union set itself the goal to "regain the conditions for full employment" by 2010. In order to reach that goal the EU should "become the most competitive and dynamic knowledge-based economy in the world" aiming at an average annual economic growth rate of 3\%. Referring to the "European social model" the EU intends to combine "sustainable economic growth with more and better jobs and greater social cohesion" (European Council 2000). Later, the Barcelona European Council in March 2002 confirmed the notion of the "European social model" which should be "based on good economic performance, a high level of social protection and education and social dialogue." Consequently, the European Council called for "balanced efforts on both the economic and social fronts" (European Council 2002).

Considering the poor economic developments in recent years, the EU seems to be further than ever away from achieving the Lisbon targets. Moreover, with the currently dominating economic policy approach as laid down in the "Broad Economic Policy Guidelines" and the "European Employment Strategy" the EU has no convincing strategy to overcome the problem of mass unemployment. ${ }^{8}$ The EU policy recommendations made regarding wage policy and collective bargaining are particularly misleading because they have a strong deflationary bias and would contribute to further redistribution from labour to capital income. Instead of continuing with a policy of wage restraint as demanded by the EU, wage increases should be in line with average growth of productivity plus the inflation target set by the ECB. Such a growth and stability oriented wage policy would help to stabilise consumer demand and would give the ECB the opportunity for a more expansive monetary policy without a negative impact for price stability.

The EU demand for more wage differentiation is not convincing from an economic point of view and would further undermine the notion of the European social model which aims at "high-road development" combining high productivity and equality. Instead, the EU should think about strategies on how to contain the already existing low-wage sector in Europe, e.g. by the introduction of a European minimum wage. ${ }^{9}$ Besides this, the EU should not call for a further decentralisation of collective bargaining but for a re-strengthening of multi-employer

$8 \quad$ For a more detailed discussion of the Broad Economic Policy Guidelines see: Hein and Niechoj (2004). For a critical assessment of the European Employment Strategy see: Watt (2004).

9 Interesting proposals for the introduction of a European minimum wage (defined as a certain minimum related to national purchasing power) have recently been developed by the French Parti Socialiste (see: Filoche 2004). 
bargaining at sectoral and national levels. Coordinated collective bargaining is an indispensable precondition for a macroeconomic orientation of wage policy as well as for a restriction of growing wage inequality.

Considering the new macroeconomic regime in Europe with integrated product markets and at least within EMU - a common monetary policy, what is finally required is a European coordination of wage policy. The latter would have to overcome the current 'beggar-thyneighbour' approach whereby European countries try to improve their price competitiveness through a policy of wage restraint or unpaid working time extension increasing the risks of a deflationary spiral in Europe (Hein, Schulten \& Truger 2004). In recent years it has been the European trade unions which have started some political initiatives aiming at a European coordination of wage policy in order to prevent competitive underbidding of labour costs and wage dumping (Schulten 2003, 2004a, 2004b). So far, these initiatives have not only had to tackle various political and institutional difficulties but have also completely lacked any support from European employers' associations and EU institutions. From the employers point of view this is understandable because they have considerable advantages in the current situation. From the EU perspective, however, this is rather incomprehensible since a more growth and employment-creating macroeconomic regime would require a European coordination of wage policy in order to achieve macroeconomic policy coordination between monetary, fiscal and wage policy. ${ }^{10}$

\section{References}

Aidt, T. and Z. Tzannatos (2002) Unions and Collective Bargaining. Economic Effects in a Global Environment, Washington D.C.: The World Bank.

Allsopp, C. (2002) 'The Future of Macroeconomic Policy in the European Union', Bank of England, External MPC Unit, Discussion Paper No. 7, London.

Baker, D., A. Glyn, D. Howell and J. Schmitt (2002) 'Labor Market Institutions and Unemployment: A Critival Assessment of the Cross-Country Evidence', CEPA Working Paper 2002-17, Center for Economic Policy Analysis, New School University, New York.

Bieling, H.-J. and T. Schulten (2003) 'Competitive Restructuring' and Industrial Relations within the European Union: Corporatist Involvement and Beyond, in: A. W. Cafruny and M. Ryner (eds.), A Ruined Fortress? Neoliberal Hegemony and Transformation in Europe, Lanhan (USA): Rowman \& Littefield Publishers, 231-260.

$10 \quad$ For an extensive discussion of the necessity and the potentials of such a European coordination of overall economic policy see Hein and Truger (2004a, 2004b). 
Bibow, J. (2002) 'The monetary policies of the European Central Bank and the euro's (mal-) performance: A stability oriented assessment', in: International Review of Applied Economics, 16 (1), 31-50.

Blanchard, O. and L.F. Katz (1997) 'What we know and do not know about the natural rate of unemployment', in: Journal of Economic Perspectives, 11 (1), 51-72.

Boeri, T., A. Brugiavini and L. Calmfors (eds.) (2001) The Role of Unions in the Twenty-First Century, A Report for the Fondazione Rodolfo Debenedetti, Oxford: University Press.

European Commission (2003a) 'Broad guidelines of the economic policies of the Member States and the Community (for the 2003-05 period)' in: European Economy, 74 (4), Office for Official Publications of the EC. Luxembourg.

European Commission (2003b) Employment in Europe 2003. Recent Trends and Prospects, Luxembourg: European Communities.

European Commission (2004): European Economy No. 4, Statistical Annex Spring 2004.

European Council (2000) Presidency Conclusion, Lisbon European Council 23 and 24 March 2000.

European Council (2002) Presidency Conclusion, Barcelona European Council 15 and 16 March 2002.

Fajertag, G. and P. Pochet (eds.) (2000) Social pacts in Europe - New Dynamics, Brussels: ETUI.

Filoche, G. (2004) 'L'Europe et le Smic Unique Européen', in: Démocratie \& Socialisme, 4 June 2004 [www.democratie-socialisme.org/article.php3?id_article=415].

Fisher, I. (1933) 'The debt-deflation theory of great depressions', in: Econometrica, 1, 337-357.

Franzese, R.J. (2001): 'Strategic interaction of monetary policymakers and wage/price bargainers: a review with implications for the European common-currency area', in: Empirica, 28, 457-486.

Hein, E. (2002a) 'Central bank independence, labour market institutions and the perspectives for inflation and employment in the European Monetary Union', in: Political Economy. Review of Political Economy and Social Sciences, 10, 37-64.

Hein, E. (2002b): 'Monetary policy and wage bargaining in the EMU: Restrictive ECB policies, high unemployment, nominal wage restraint and inflation above the target', in: Banca Nazionale del Lavoro Quarterly Review, 55, 299-337.

Hein, E. (2004) ,Die NAIRU - eine post-keynesianische Interpretation', Intervention. Zeitschrift für Ökonomie, 1, 43-66.

Hein, E. and T. Niechoj (2004) 'Die 'Grundzüge der Wirtschaftspolitik' - Leitlinien für ein dauerhaftes Wachstum in der EU?', in: WSI-Mitteilungen, 57 (8), 407-413.

Hein, E., T. Schulten and A. Truger (2004) 'Wage trends and deflation risks in Germany and Europe', WSI Discussion Paper, No. 124, WSI in der Hans Boeckler Stiftung, Duesseldorf.

Hein, E. and A. Truger (2004a) 'European Monetary Union: nominal convergence, real divergence and slow growth?', in: Structural Change and Economic Dynamics, forthcoming.

Hein, E. and A. Truger (2004b) 'Macroeconomic co-ordination as an economic policy concept - opportunities and obstacles in the EMU', in: E. Hein, T. Niechoj, T. Schulten and A. Truger (eds.), Macro-economic co-operation and the role of trade unions, Bruxelles: ETUI, forthcoming.

Hein, E. and A. Truger (2004c) 'Whatever happened to Germany? Is the decline of the former European key currency country caused by structural sclerosis or by macroeconomic mismanagement?', in: International Review of Applied Economics, forthcoming.

Howell, D.R. and F. Huebler (2004) 'Wage Compression and the Unemployment Crisis: Labor Market Institutions, Skills, and Inequality-Unemployment Tradeoffs', in: D. R. Howell (ed.), Fighting Unemployment: The Limits of Free Market Orthodoxy, Oxford: University Press, forthcoming. 
International Monetary Fund (2003) Deflation: Determinants, Risks and Policy Options - Findings of an Interdepartmental Task Force, Washington, D.C..

Kalecki, M. (1943) 'Political Aspects of Full Employment', in: Collected Works of Michal Kalecki Vol. I, (edited by J. Osiatynsk), Oxford: Clarendon Press 1990, 347-356.

Kalecki, M. (1954) The Theory of Economic Dynamics, London: George Allen and Unwin.

Kalecki, M. (1969) Studies in the Theory of Business Cycles, 1933 - 1939, London: Basil Blackwell.

Keynes, J.M. (1936) The General Theory of Employment, Interest, and Money, in: The Collected Writings of J.M. Keynes, Vol. VII, London, Basingstoke: MacMillan, 1973.

Lavoie, M. (2001) 'Pricing', in: R.P.F. Holt and S. Pressman (eds.), A New Guide to Post Keynesian Economics, London, New York: Routledge, 21-31.

Lodovici, M. S. (2000) 'The Dynamics of Labour Market Reform in European Countries', in: G. Esping-Andersen and M. Regini (eds.), Why Deregulate Labour Markets? Oxford: University Press, $30-65$.

Marx, K. (1867) Capital Volume 1, London: Penguin Classics 1990.

OECD (2004) 'Wage-setting Institutions and Outcomes' in: OECD Employment Outlook 2004, Paris: OECD, 127-179.

Petit, P. (1998) The Reconstruction of Full Employment. A policy challenge for Europe, Working Paper No. I/6 of the Working Group: Alternative Economic Policy for Europe (EuromemorandumGroup) [http://www.memo-europe.uni-bremen.de/downloads/Petit198.PDF]

Sawyer, M. (2001) 'The NAIRU: a critical appraisal', in: P. Arestis and M. Sawyer, M. (eds.), Money, Finance and Capitalist Development, Cheltenham: Edward Elgar, 220-254.

Sawyer, M. (2002) 'The NAIRU, aggregate demand and investment', in: Metroeconomica, 53, 66-94.

Sisson, K. (2001) 'Pacts for employment and competitiveness - an opportunity to reflect on the role and practice of collective bargaining', in: Transfer 7, 1-16.

Schulten, T. (2003) 'Europeanisation of Collective Bargaining - Trade Union Initiatives for a Transnational Coordination of Collective Bargaining Policy', in: B. Keller and H.-W. Platzer (eds.) Industrial Relations and European Integration. Trans- and Supranational Developments and Prospects, London: Ashgate, 112-136.

Schulten, T. (2004a) Solidarische Lohnpolitik in Europa. Zur Politischen Ökonomie der Gewerkschaften, Hamburg: VSA.

Schulten, T. (2004b) 'Foundations and Perspectives of Trade Union Wage Policy in Europe', in: E. Hein, T. Niechoj, T. Schulten and A. Truger (eds.), Macro-economic co-operation and the role of trade unions, Bruxelles: ETUI, forthcoming.

Snowdon, B., H. Vane and P. Wynarczyk, P. (1994) A Modern Guide to Macroeconomics. An Introduction to Competing Schools of Thought, Cheltenham: Edward Elgar.

Soskice, D. and T. Iversen (2001) 'Multiple wage bargaining systems in the single European currency area', in: Empirica, 28, 435-56.

Traxler, F., S. Blaschke and B. Kittel (2001) National Labor Relations in Internationalized Markets, Oxford:

Watt, A. (2004) 'Reform of the European Employment Strategy after Five Years: A Change of Course or Merely of Presentation?' in: European Journal of Industrial Relations 10 (2), 117-137. 


\section{Appendix}

Figure 1a: Unemployment rate and real wage growth in Germany, 1960 - 2004, in \% Source: European Commission (2004), AMECO database

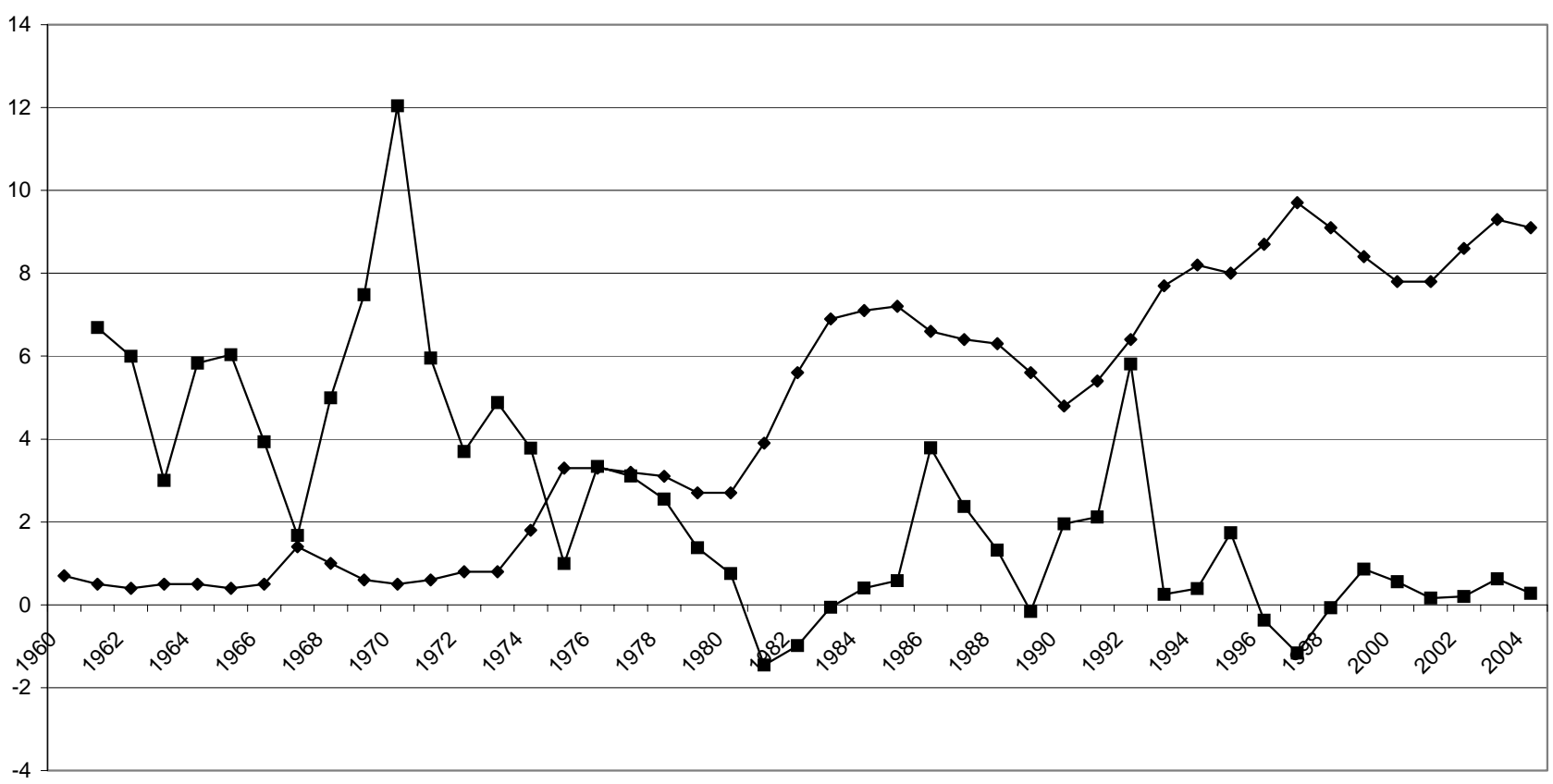

Unemployment rate - Annual growth rate of real compensation per employee, deflator private consumption: total economy

Figure 1b: Unemployment rate and real wage growth in France, 1960 - 2004, in \% Source: European Commission (2004), AMECO database

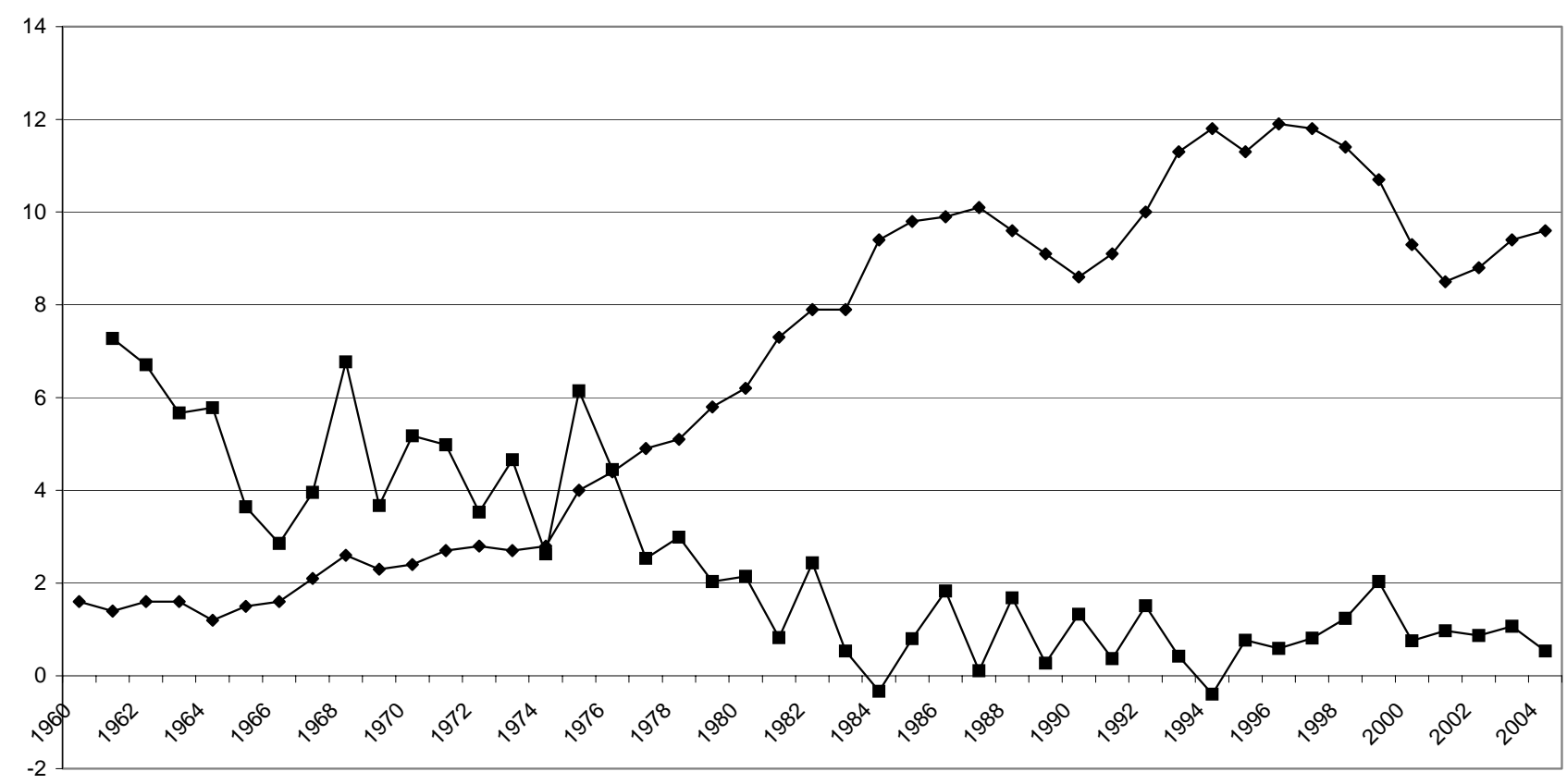


Figure 1c: Unemployment rate and real wage growth in the UK, 1960 - 2004, in \% Source: European Commission (2004), AMECO database

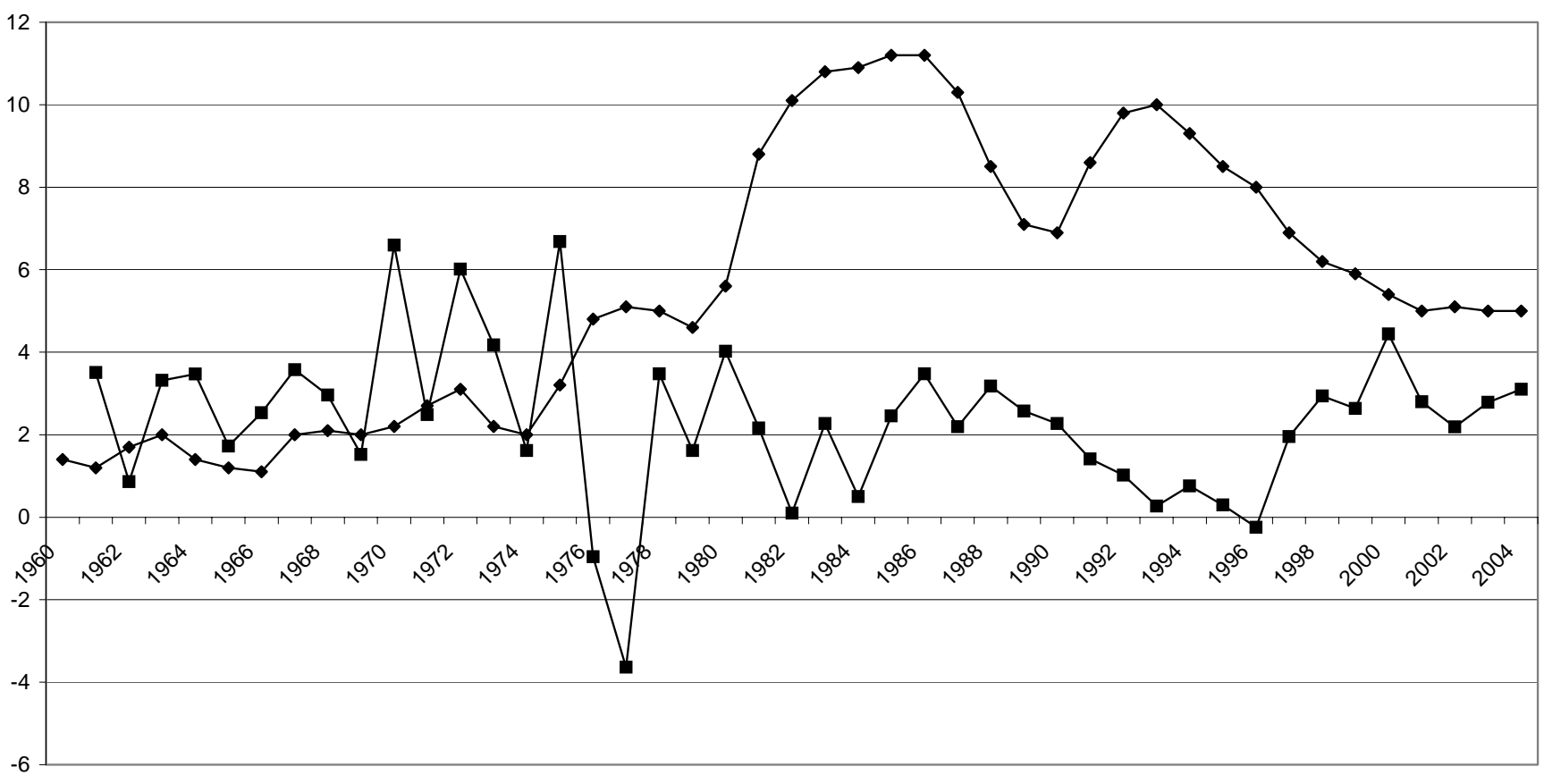

$\rightarrow-$ Unemployment rate $\rightarrow-$ Annual growth rate of real compensation per employee, deflator private consumption: total economy

Figure 1d: Unemployment rate and real wage growth in the USA, 1960 - 2004, in \% Source: European Commission (2004), AMECO database

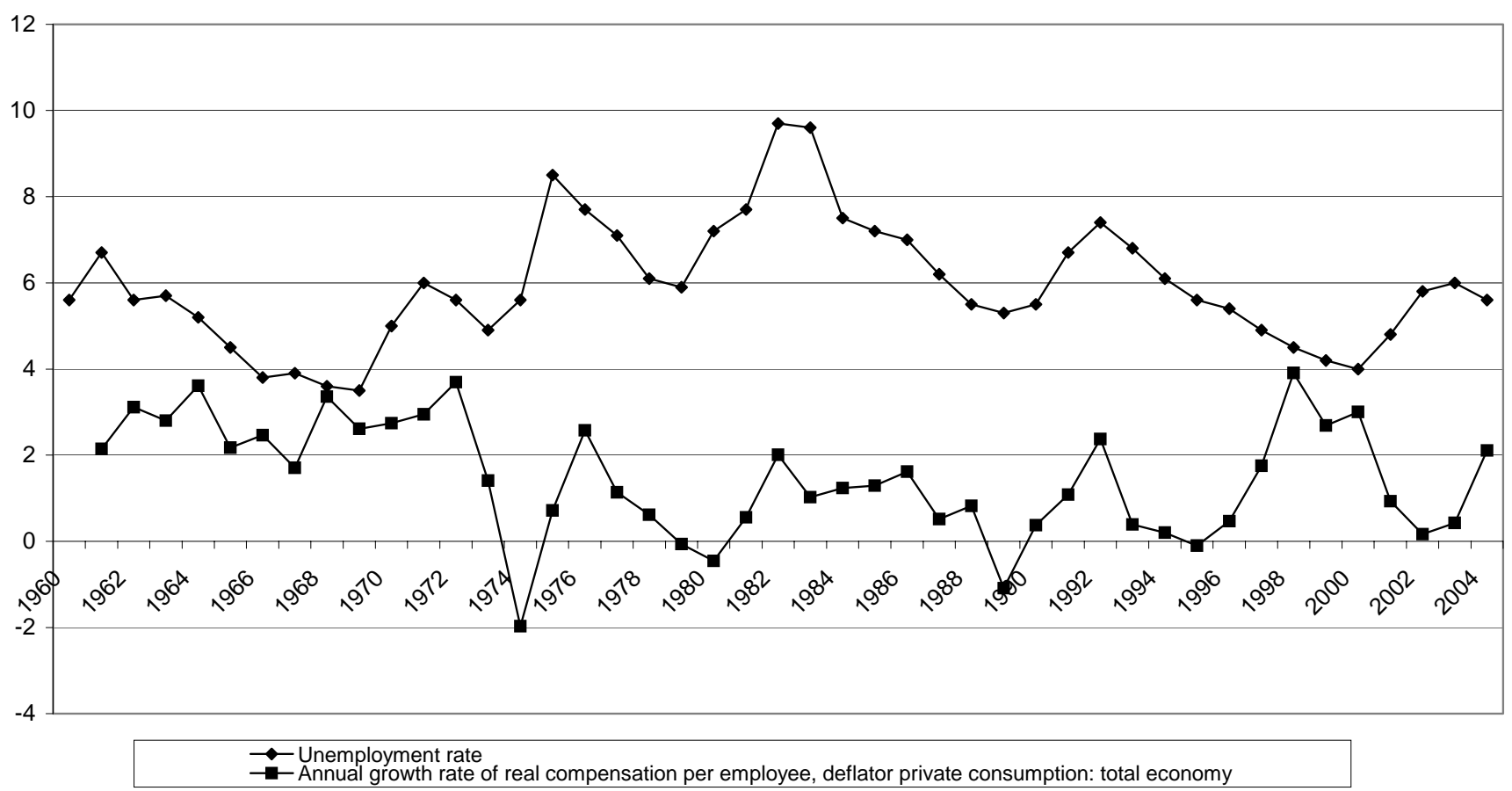


24

Figure 2a: Inflation rate and nominal wage growth in Germany, 1960 - 2004, in \% Source: European Commission (2004), AMECO database

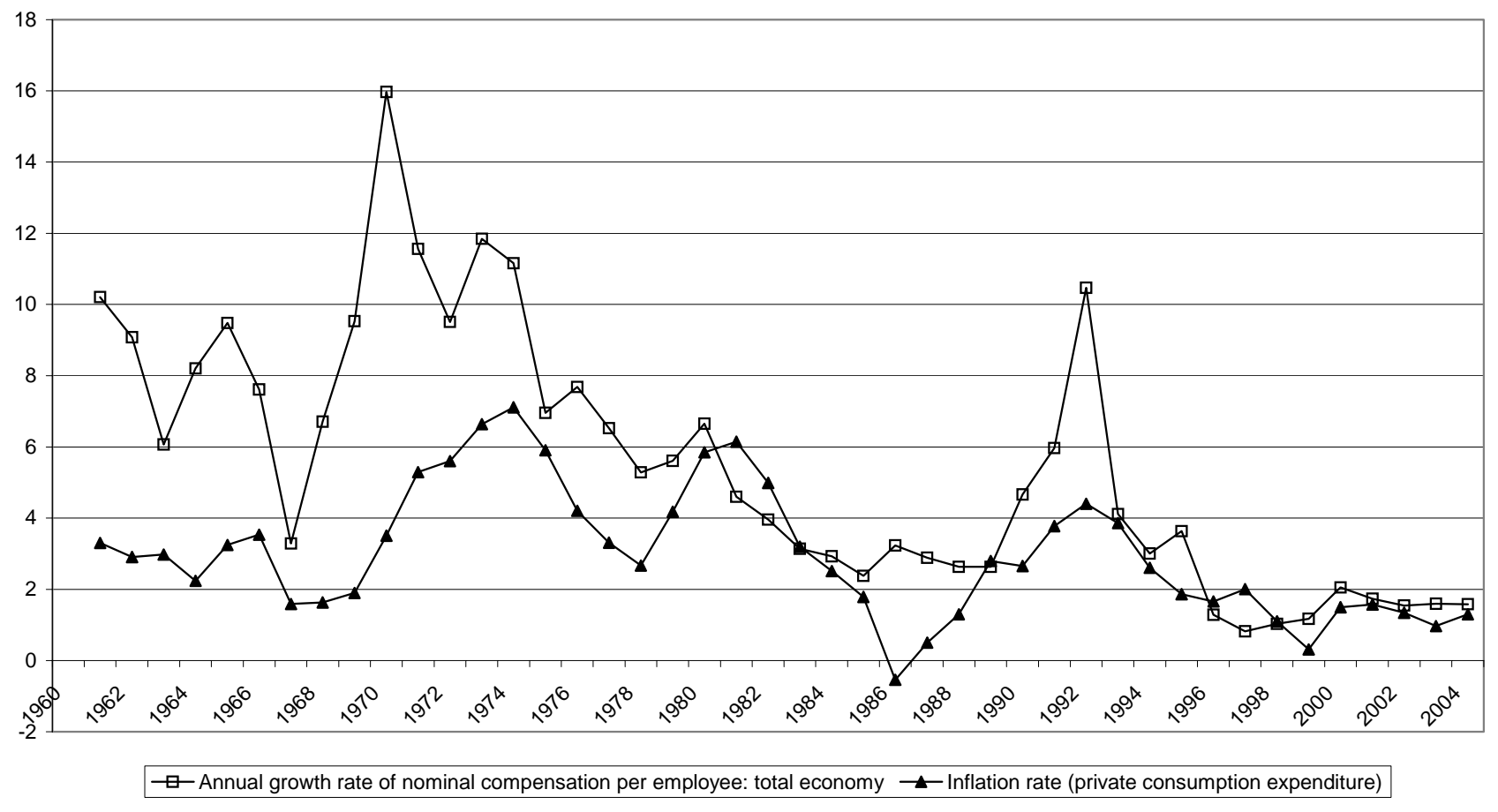

Figure 2b: Inflation rate and nominal wage growth in France, 1960 - 2004, in \% Source: European Commission (2004), AMECO database

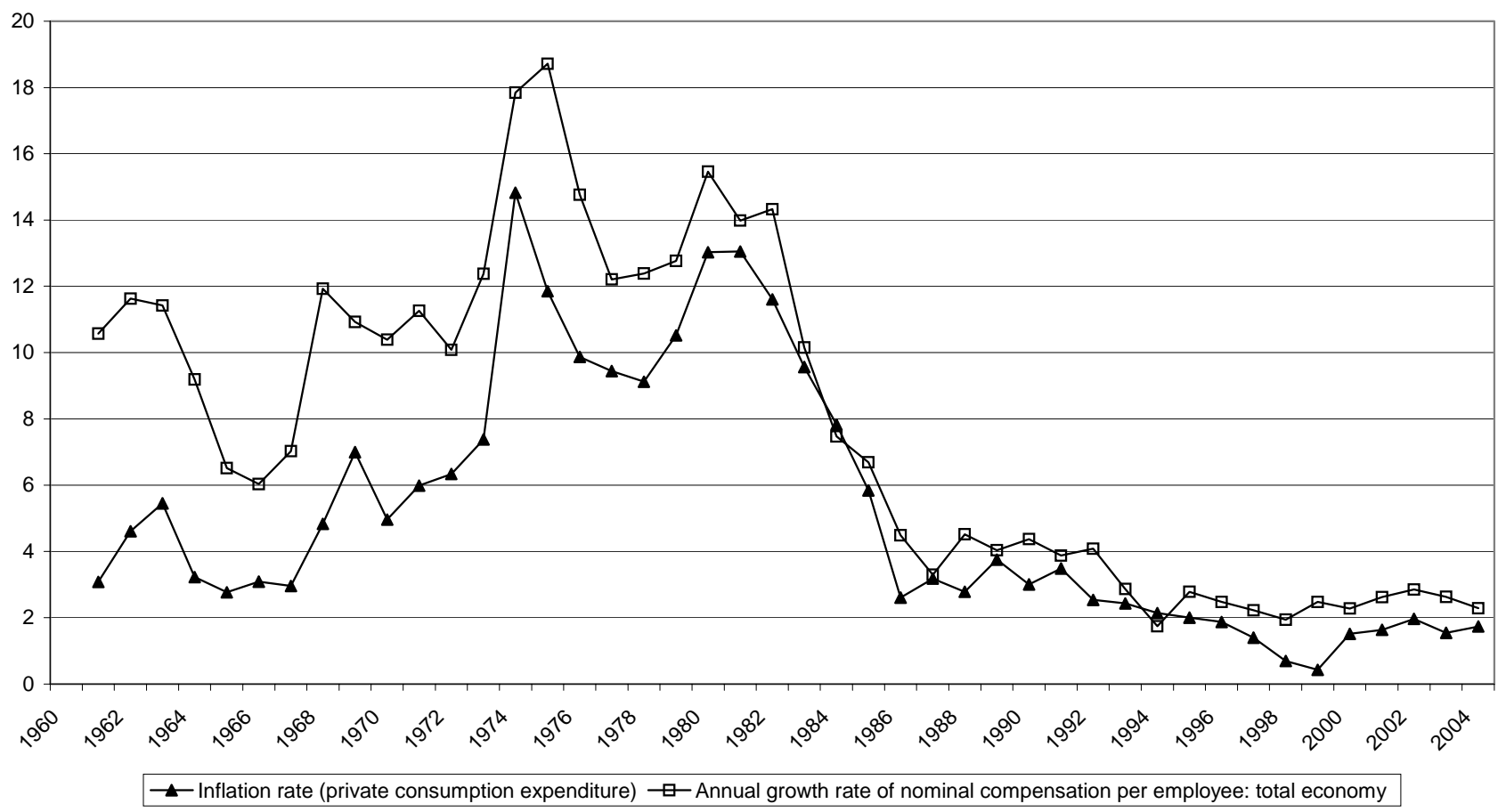


Figure 2c: Inflation rate and nominal wage growth in the UK, 1960 - 2004, in \% Source: European Commission (2004), AMECO database

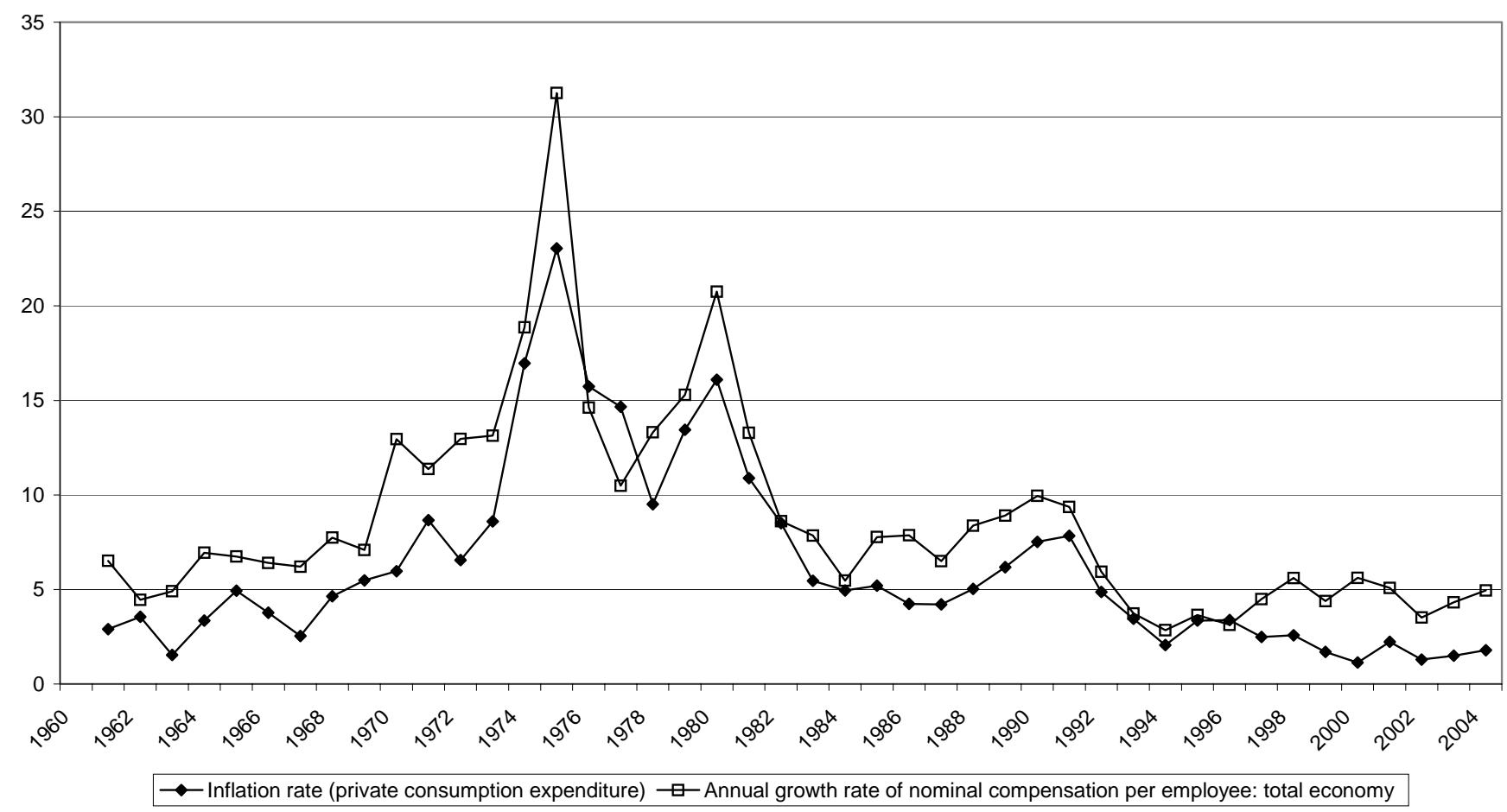

Figure 2d: Inflation rate and nominal wage growth in the USA, 1960 - 2004, in \% Source: European Commission (2004), AMECO database

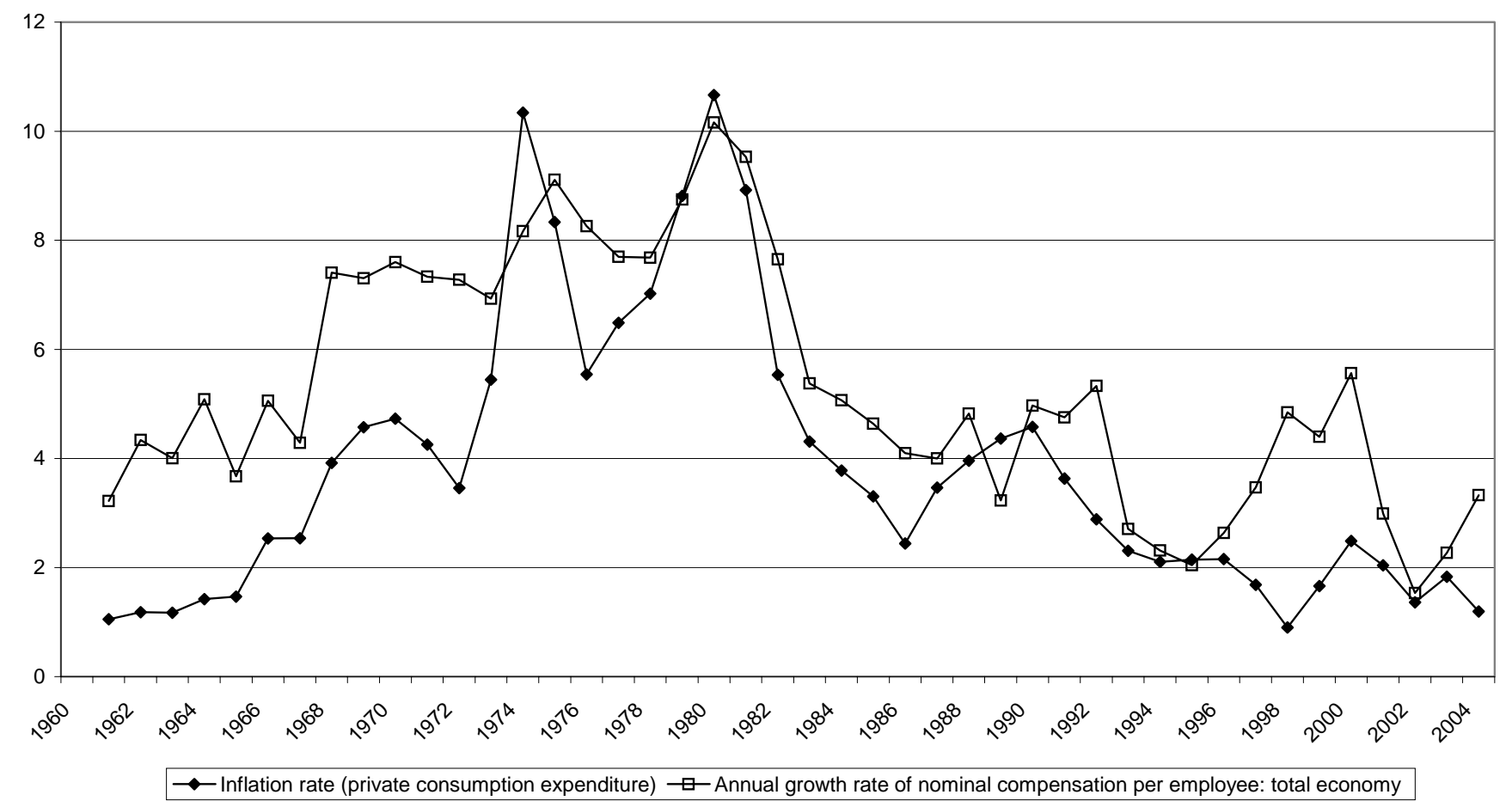


Figure 3a: Unemployment rate \& nominal wage growth in Germany, 1960- 2004, in \% Source: European Commission (2004), AMECO database

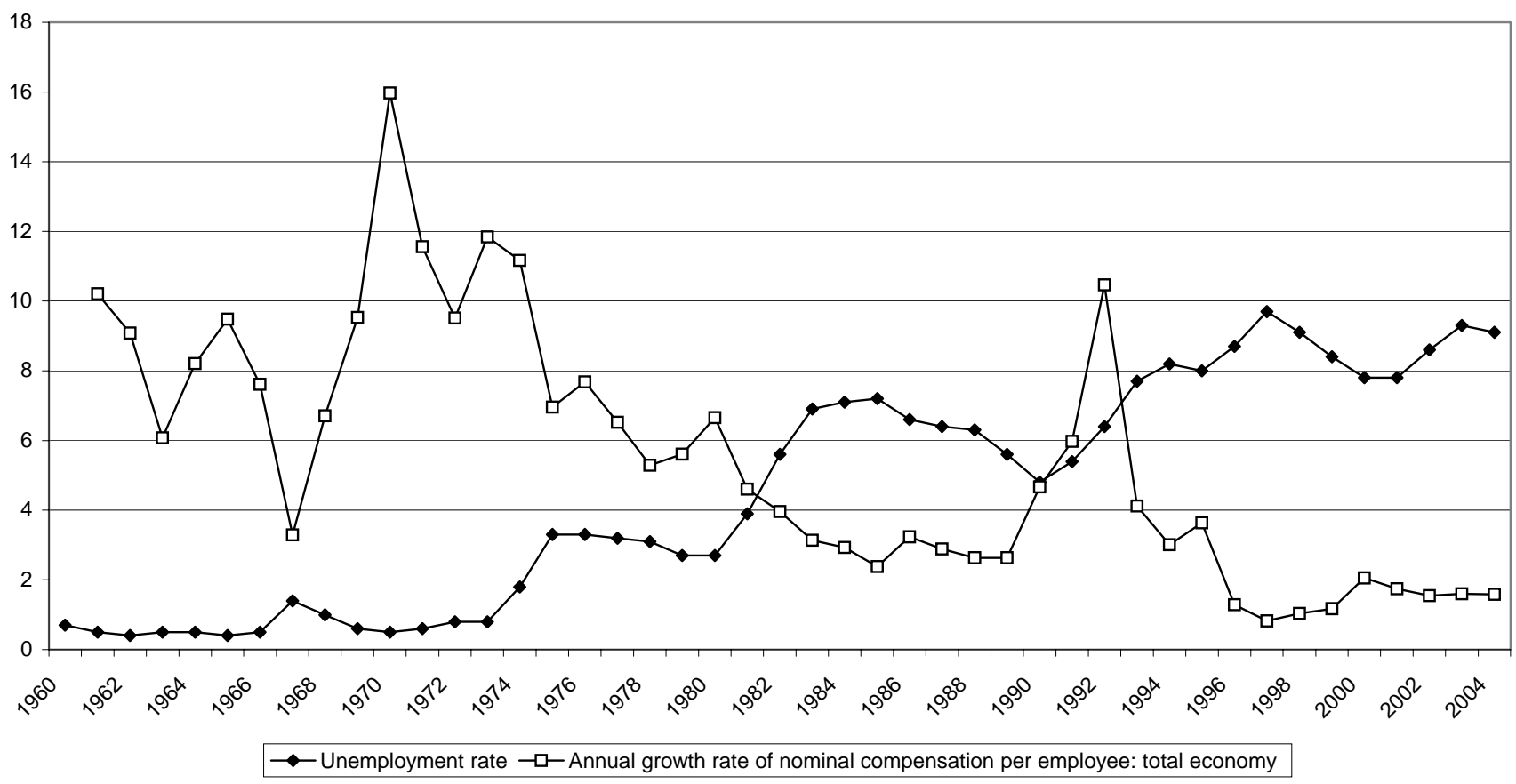

Figure 3b: Unemployment rate and nominal wage growth in France, 1960 - 2004, in \% Source: European Commission (2004), AMECO database

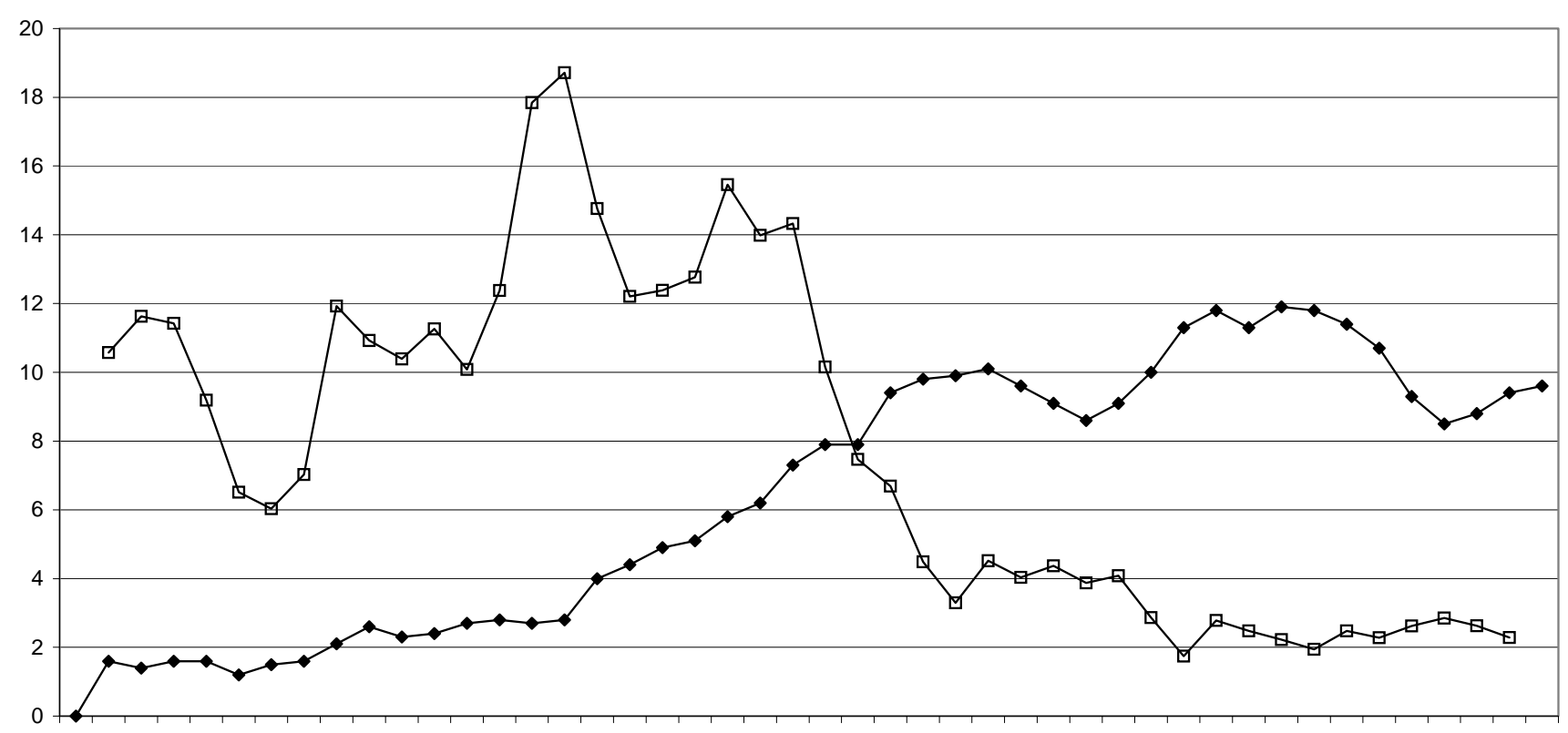

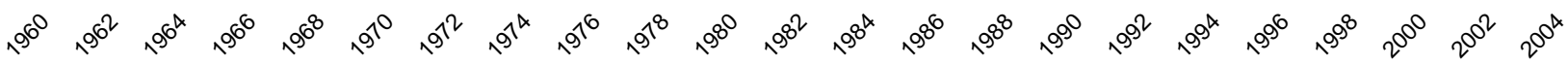


Figure 3c: Unemployment rate and nominal wage growth in the UK, 1960 - 2004, in \% Source: European Commission (2004), AMECO database

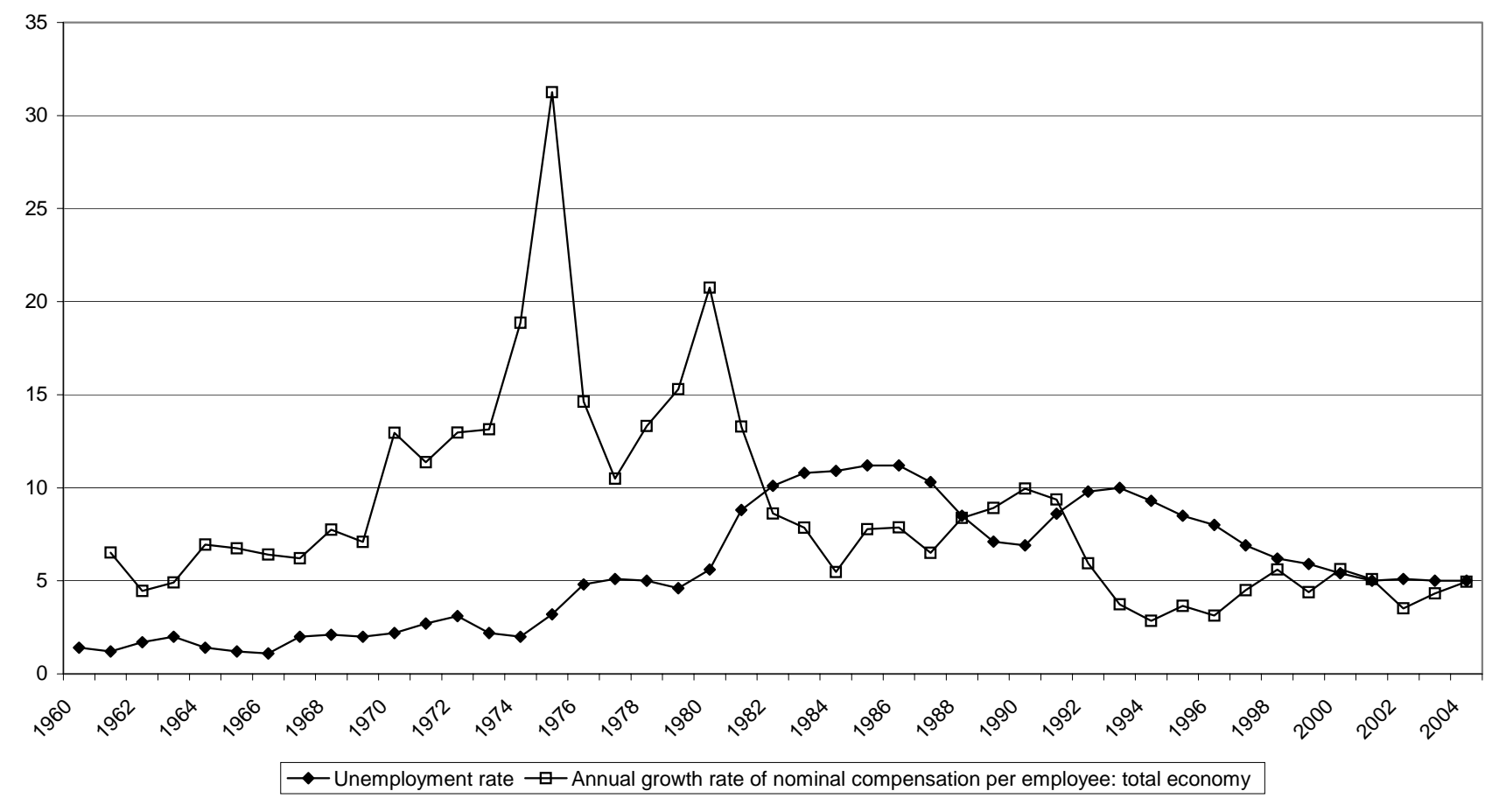

Figure 3d: Unemployment rate \& nominal wage growth in the USA, 1960- 2004, in \% Source: European Commission (2004), AMECO database

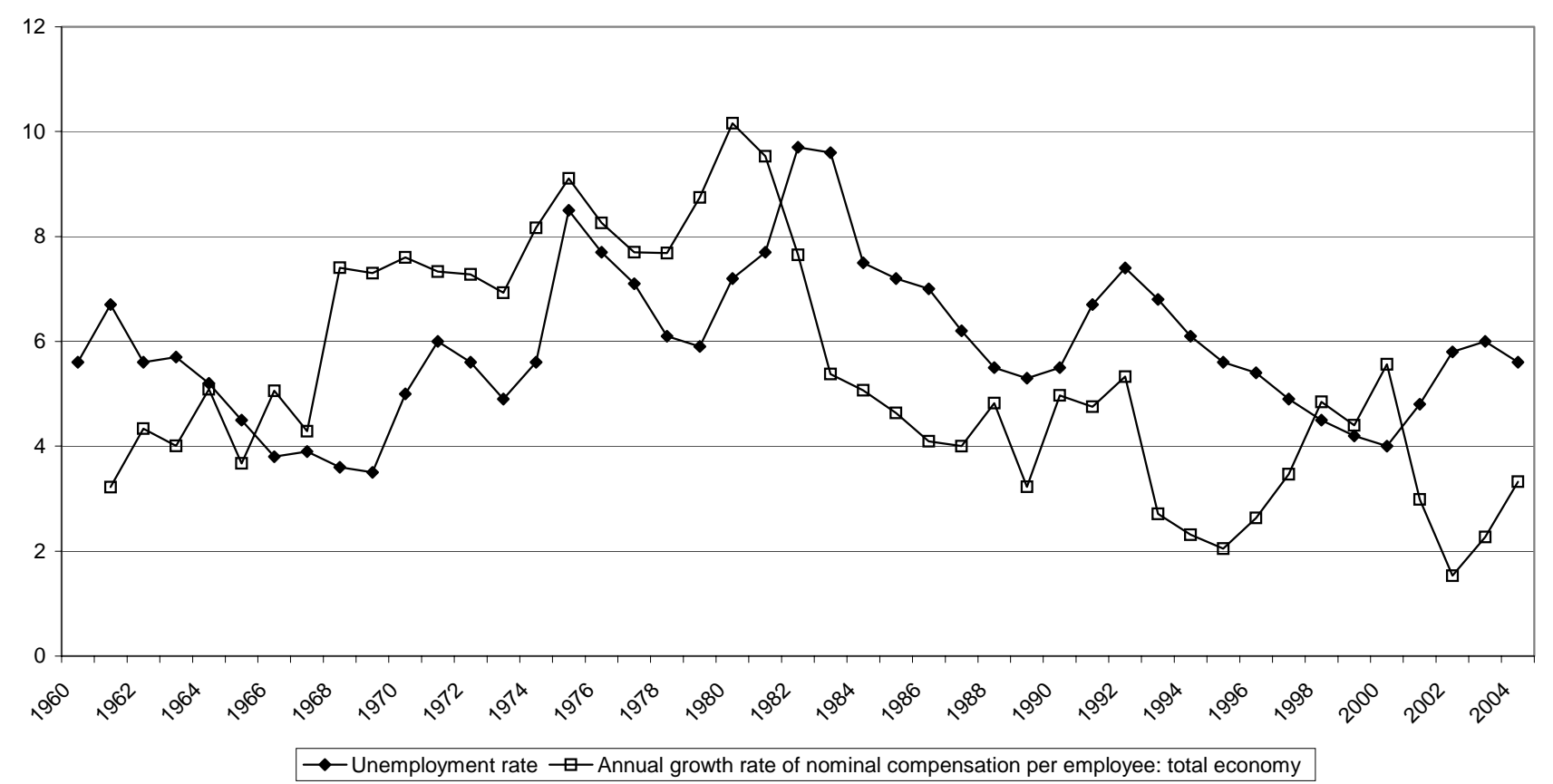


Figure 4a: Unemployment rate and labour income share in Germany, 1960 - 2004, in \% Source: European Commission (2004), AMECO database

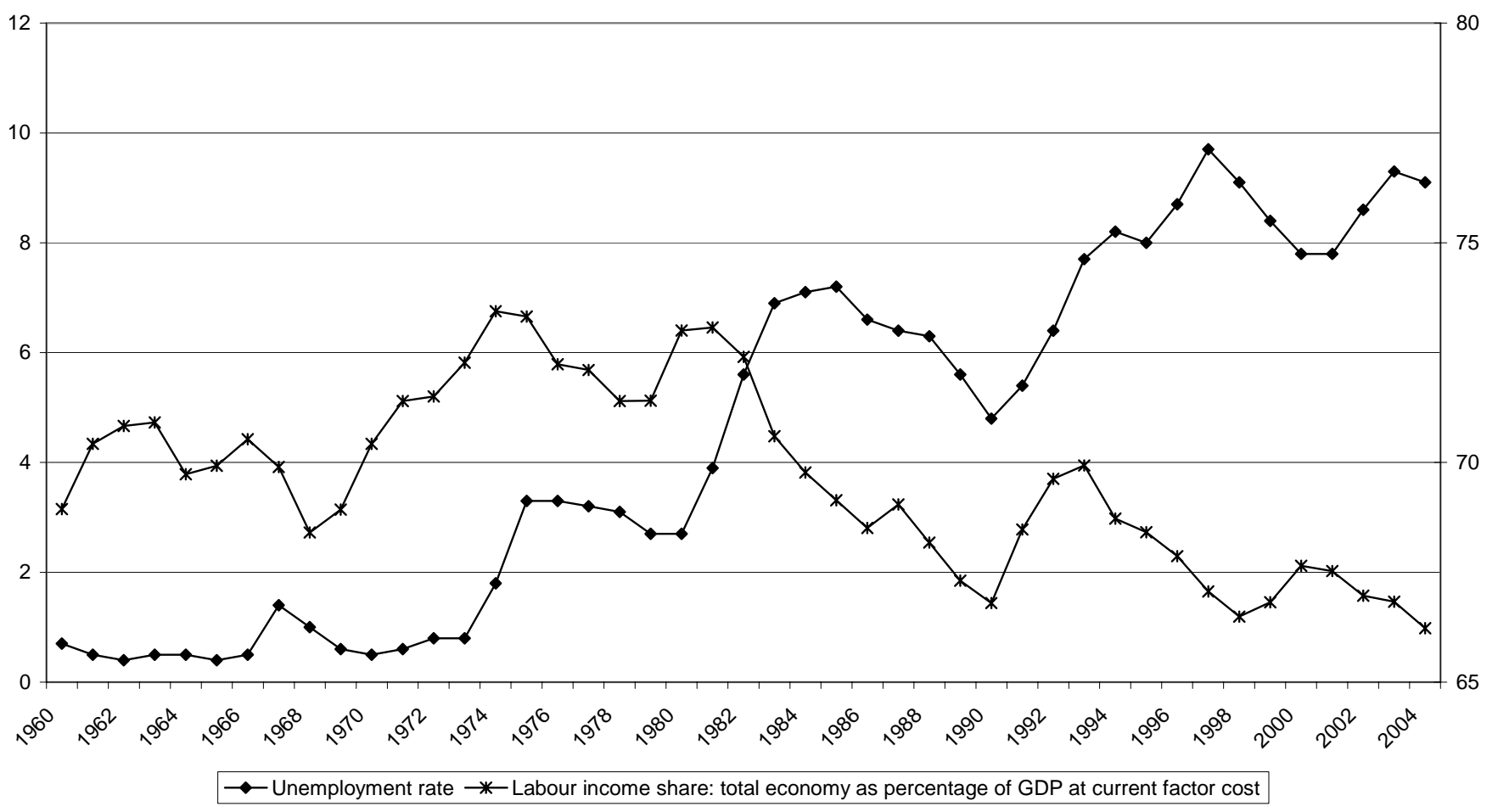

Figure 4b: Unemployment rate and labour income share in France, 1960 - 2004, in \% Source: European Commission (2004), AMECO database

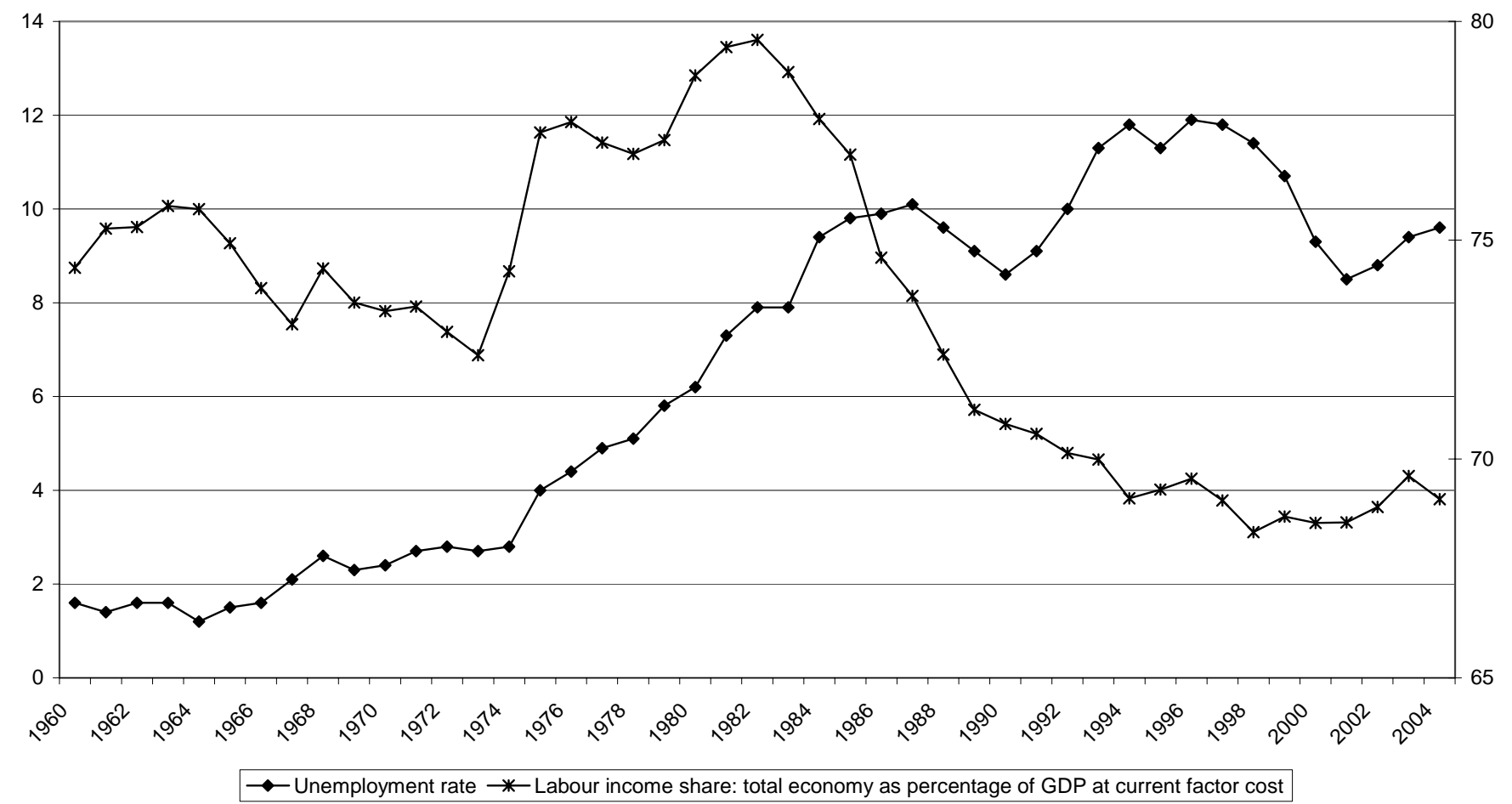


Figure 4c: Unemployment rate and labour income share in the UK, 1960 - 2004, in \% Source: European Commission (2004), AMECO database

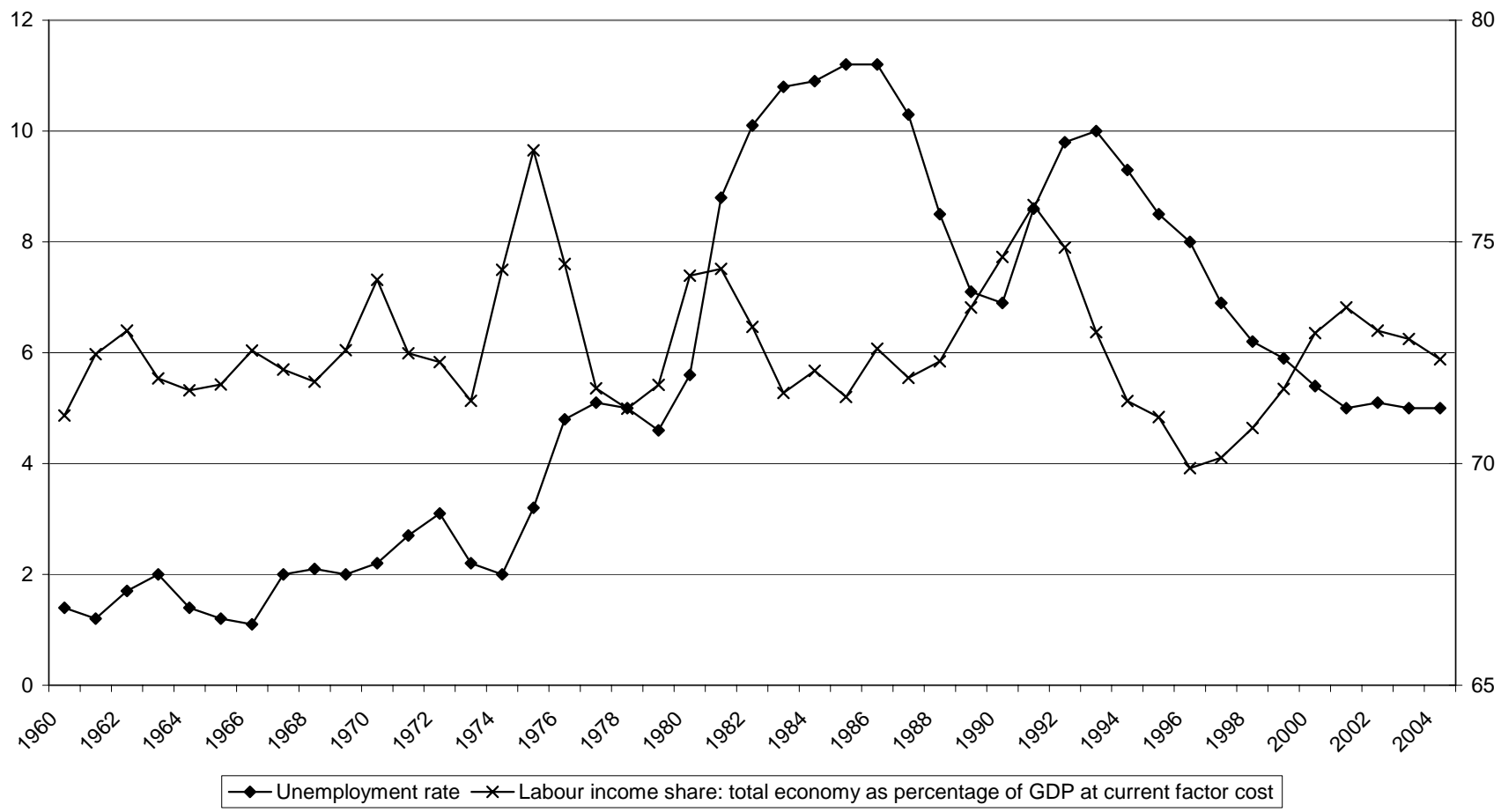

Figure 4d: Unemployment rate and labour income share in the USA, 1960 - 2004, in \% Source: European Commission (2004), AMECO database

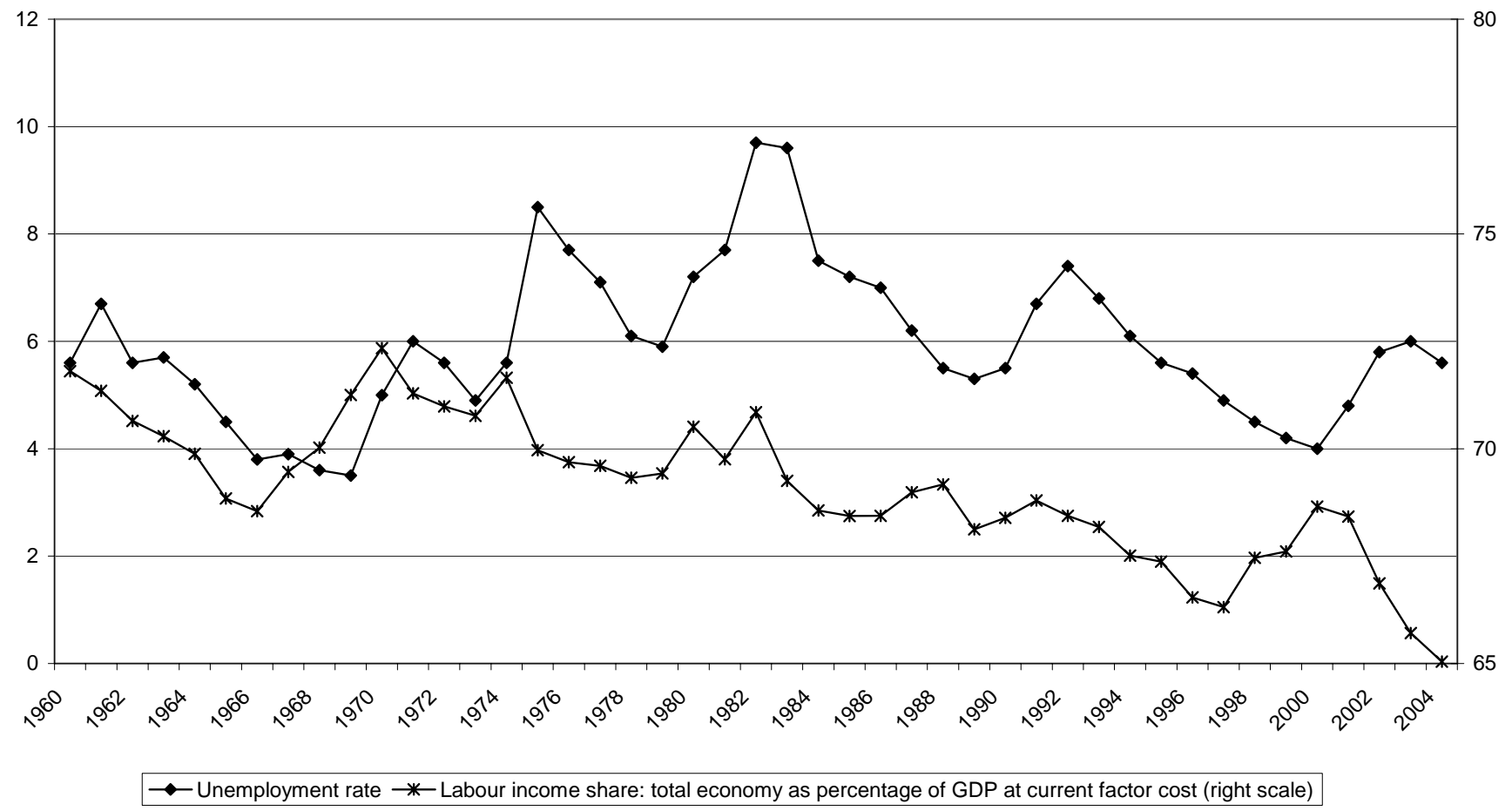




\section{Published WSI-Discussion Papers since 2000}

78. Seifert, Hartmut: Competition, Flexibility and Working Hours, Januar 2000

79. Bahnmüller, Reinhard / Bispinck, Reinhard / Weiler, Anni: Tarifpolitik und Lohnbildung in Deutschland am Beispiel ausgewählter Wirtschaftszweige, Februar 2000

80. Seifert, Hartmut: New Approaches to Working Time Policy in Germany: The 28,8 Hour Working Week at Volkswagen Company, Februar 2000

81. Truger, Achim: Kritisches zu den Wohlfahrtsaussagen der neueren Steuertheorie, Februar 2000

82. Ebert, Daniela: Bestimmungsfaktoren der Beschäftigung in der Bundesrepublik. Eine empirische Analyse der Faktorsubstitutionshypothese unter Berücksichtigung einer Alternativhypothese, Februar 2000

83. Truger, Achim: Steuerreformen für mehr Beschäftigung?, Februar 2000

84. Bispinck, Reinhard / Schulten, Thorsten: Alliance for Jobs: Is Germany following the path of "competitive corporatism“?, April 2000

85. Klammer, Ute: Working women in the age of flexibilitiy - new diversities, new needs for social protection, April 2000

86. Ziegler, Astrid: Die Europäischen Strukturfonds 2000 - 2006 - Zu den Einflussmöglichkeiten der Sozialpartner in der Bundesrepublik Deutschland, April 2000

87. Truger, Achim: Ökologische Steuerreformen in Europa - Wo steht Deutschland?, Juni 2000

88. Truger, Achim: Konstitutionelle Ökonomik, Staatsversagen und „Wissenschaftsversagen“, September 2000

89. Klammer, Ute: Old problems - new solutions? - Working mothers between social policies and social practices - October 2000

90. Pelz, Thomas / Ziegler, Astrid: Synopse aktueller Untersuchungen zur Wirtschaftsentwicklung in den neuen Bundesländern, Dezember 2000

91. Schulte, Christiane / Ziegler, Astrid: Wettbewerbsmodelle in der deutschen Wirtschafts- und Strukturpolitik - ein neuer Fördertyp, Dezember 2000

92. Schulten, Thorsten: Solidarische Lohnpolitik in Europa - Ansätze und Perspektiven einer Europäisierung gewerkschaftlicher Lohnpolitik, März 2001

93. Sitte, Ralf: Zwischen Konzeption und Obstruktion - eine Betrachtung zum K(r)ampf um die Ökosteuer, April 2001 
94. Trautwein-Kalms, Gudrun/Viedenz, Jürgen: Dienstleistungsarbeit und Interessenvertretung, Sonderauswertung der WSI-Betriebsräte-Befragung 2000 für den privaten Dienstleistungsbereich, Mai 2001

95. Hein, Eckhard: Institutions and Macroeconomic Performance: Central Bank Independence, Labour Market Institutions and the Perspectives for Inflation and Employment in the European Monetary Union, June 2001

96. Ziegler, Astrid/Breuer, Tanja: Mehr Beschäftigung durch Europa? Umsetzung der europäischen Beschäftigungsstrategie in Ostdeutschland, August 2001

97. Behrens, Martin/Fichter, Michael/Frege, Carola M.: Unions in Germany Searching to Regain the Initiative - Project Reportfor the Hans-Böckler-Stiftung Projekt Nr. 2000-250-2, August 2001

98. Truger, Achim: Fiskalpolitik in der Europäischen Wirtschafts- und Währungsunion, September 2001

99. Bieling, Hans-Jürgen/Schulten, Thorsten: Competitive Restructuring and Industrial Relations within the European Union: Corporatist Involvement and Beyond?, November 2001

100. Bartsch, Klaus/Hein, Eckhard/Truger, Achim: Zur Interdependenz von Geld- und Lohnpolitik: Makroökonometrische Ex-post und Ex-ante Simulationen verschiedener Szenarien für die Bundesrepublik Deutschland, November 2001

101. Schulten, Thorsten: Europeanisation of Collective Bargaining - An Overview on Trade Union Initiatives for a Transnational Coordination of Collective Bargaining Policy, Mai 2001

102. Hein, Eckhard: Money, Interest, and Capital Accumulation in Karl Marx's Economics: A Monetary Interpretation, Juni 2002

103. Hein, Eckhard: Monetary Policy and Wage Bargaining in the EMU: Restrictive ECB policies, high unemployment, nominal wage restraint and rising inflation, Juni 2002

104. Ziegler, Astrid: Technologiepolitik in Nordrhein-Westfalen, September 2002

105. Berger, Christiane: Technologie- und Innovationspolitikin Bayern, September 2002

106. Riedel, Jürgen: Technologie- und Innovationspolitik in Sachsen, September 2002

107. Hein, Eckhard/ Truger, Achim: European Monetary Union: Nominal Convergence, Real Divergence and Slow Growth?, September 2002

108. Bartsch, Klaus: Das makroökonometrische Deutschlandmodell LAPROSIM QD 8.3 E. Eine Übersicht über zentrale Gleichungsspezifikationen und Grundzüge des Modellverhaltens, November 2002

109. Trautwein-Kalms, Gudrun (Redaktion): Arbeits- und Leistungsbedingungen im ITBereich, Fachtagung am 7. März 2002 in Bonn im Rahmen des BMBF-Projekts: Dienst-Leistung(s)-Arbeit, Tagungsdokumentation, Januar 2003 
110. Sitte, Ralf: Soziale Sicherung unter Rot-Grün - Zur Entwicklung von Sozialpolitik und Sozialbudget seit 1998, Januar 2003

111. Josten, Stefan Dietrich/ Truger Achim: The Political Economy of Growth and Distribution. A Theoretical Critique, März 2003

112. Ahlers, Elke: Arbeitsbedingungen, Leistungsdruck, Gesundheit am Arbeitsplatz März 2003

113. Hein, Eckhard: Die NAIRU - eine post-keynesianische Interpretation, März 2003

114. Ziegler, Astrid: Synopse wichtiger Positionen zur Reformdebatte der Europäischen Strukturpolitik nach 2006, April 2003

115. Tangian, Andranik: An Econometric decision model for equalizing regional unemployment in West and East Germany, July 2003

116. Ziegler, Astrid: Die europäische Strukturpolitik nach 2006 - Anforderungen an ein neues Konzept der europäischen Strukturfonds im Zeitraum 2007-2013, August 2003

117. Bäcker, Gerhard/ Koch Angelika: Mini- und Midi-Jobs als Niedrigeinkommensstrategie in der Arbeitsmarktpolitik. "Erfolgsstory" oder Festschreibung des geschlechtsspezifisch segregierten Arbeitsmarktes?, August 2003

118. Truger, Achim: Germany's Poor Economic Performance in the Last Decade: It's the Macroeconomy, not Institutional Sclerosis, September 2003

119. Tangian, Andranik S.: Optimizing German regional policy-2004: A study based on empirical data from 1994 to 2001, December 2003

120. Truger, Achim: Verteilungs- und beschäftigungspolitische Risiken aktueller Steuerreformkonzepte: Eine Analyse mit Steuerbelastungsvergleichen für konkrete Haushaltstypen, Februar 2004

121. Niechoj, Torsten: Gewerkschaften und keynesianische Koordinierung in Europa. Chancen, Risiken und Umsetzungshürden, März 2004

122. Tangian, Andranik, S.: Defining the flexicurity index in application to European countries, April 2004

123. Torsten Niechoj: Fünf Jahre Makroökonomischer Dialog - Was wurde aus den ursprünglichen Intentionen?, April 2004

124. Hein, Eckhard/ Schulten, Thorsten/ Truger, Achim: Wage trends and deflation risks in Germany and Europe, Juni 2004

125. Hein, Eckhard/ Truger, Achim: Macroeconomic co-ordination as an economic policy concept - opportunities and obstacles in the EMU, Juni 2004

126. Hein, Eckard/Niechoj, Torsten: Leitlinien für ein dauerhaftes Wachstum in der EU?, Juli 2004 
127. Seifert, Hartmut: Arbeitszeitpolitischer Modellwechsel: Von der Normalarbeitszeit zu kontrollierter Flexibilität, Juli 2004

128. Hein, Eckhard/Schulten, Thorsten: Unemployment, Wages and Collective Bargaining in the European Union, September 2004

129. Schulten, Thorsten: Foundations and Perspectives of Trade Union Wage Policy in Europe, August 2004

130. Seifert, Hartmut: Flexibility through working time accounts: reconciling economic efficiency and individual time requirements, September 2004. 